\title{
İşitme Yetersizliği Yaşayanların İletişimlerine Yönelik Bir İşaret Dili Çeviri Sisteminin Geliştirilmesi ve Uzman Değerlendirmesi
}

Takdire Vişne ${ }^{1}$

\author{
Serkan Yıldırım²
}

Type/Tür:

Research/Araştırma

Received/Geliş Tarihi: October

28/28 Ekim 2019

Accepted/Kabul Tarihi: April

29/29 Nisan 2020

Page numbers/Sayfa No: 679-707

Corresponding

Author/İletişimden Sorumlu

Yazar: takdirevisne@outlook.com

\section{$\checkmark$ iThenticate}

This paper was checked for plagiarism using iThenticate during the preview process and before publication. / Bu çalışma ön inceleme sürecinde ve yayımlanmadan önce iThenticate yazılımı ile taranmıştır.

Copyright $\odot 2018$ by Cumhuriyet University, Faculty of Education. All rights reserved.
Öz

$\mathrm{Bu}$ çalışmanın amacı, iletişim ortamı olarak geliştirilen prototip İDÇS (İşaret Dili Çeviri Sistemi)'nin iletişim sürecini ve akademik başarıyı destekleme potansiyelini belirlemektir. Çalışma nitel araştırma yöntemlerinden biri olan durum çalışması ile yürütülmüştür. Araştırmanın çalışma grubunu işitme engelliler öğretmenliğinden mezun özel eğitim öğretmenleri, uzman öğreticiler ve işaret dili tercümanları olmak üzere 11 uzman oluşturmaktadır. Geliştirilen sistemle ilgili uzman görüş̧leri alınmış ve toplanan veriler analiz edilmiştir. Elde edilen veriler iletişim süreçleri ve akademik başarı olmak üzere iki tema altında toplanmıştır. İletişim süreçlerine yönelik bulgular incelendiğinde katılımcılar tarafından İDÇS'nin en çok iletişim performansını ve sosyalleşmeyi arttırma potansiyelinin olduğu düşünülmektedir. Bununla birlikte İDÇS'nin başlangıç seviyesinde öğrenme, kelime dağarcığını artırma potansiyelinin olduğu da katılımcılar tarafından ifade edilmiştir. İDÇS'nin ders çalışma süreçlerine etki potansiyelinin bulunması da elde edilen diğer bulgular arasındadır. İDÇS'nin iletişim performansını, sosyalleşmeyi, kelime dağarcı̆̆ını, akademik başarıyı, başlangıç seviyesinde işaret dili öğrenmeyi ve işaret dili öğrenmeye ilgiyi arttırma potansiyelinin olduğuna ilişkin görüşler bildirilmiştir. İşitme yetisinde oluşturabileceği tembelliğin soyutlanmaya yol açma ihtimalinin bulunduğu da elde edilen sonuçlar arasındadır.

Anahtar Kelimeler: İşaret dili çeviri sistemi, işaret dili, işitme yetersizliği, iletişim, işitme

\footnotetext{
Suggested APA Citation/Önerilen APA Atıf Biçimi:

Vişne, T., \& Yıldırım, S. (2020). İşitme yetersizliği yaşayanların iletişimlerine yönelik bir işaret dili çeviri sisteminin geliştirilmesi ve uzman değerlendirmesi. Cumhuriyet International Journal of Education, 9(3), 679-707. http://dx.doi.org/10.30703/cije.639035
}

\footnotetext{
1 Öğretmen, Milli Eğitim Bakanığı, Kahramanmaraş/Türkiye

Teacher, Ministry of Education, Kahramanmaraş/Turkey

e-mail: takdirevisne@outlook.com ORCID ID: $\underline{\text { orcid.org/0000-0002-7456-0700 }}$
}

${ }^{2}$ Dr. Öğrt. Üyesi, Atatürk Üniversitesi, Eğitim Fakültesi, Bilgisayar ve Öğretim Teknolojileri Eğitimi Bölümü,

Erzurum/Türkiye

Asst. Prof. Dr, Ataturk Univesity, Faculty of Education, Department of Computer Education and Instructional

Technology, Erzurum/Turkey

e-mail: serkanyil@gmail.com ORCID ID: orcid.org/0000-0002-8277-5963 


\title{
Development of a Sign Language Translation System for Hearing Impairment Person's Communication and Professional's Evaluations
}

\begin{abstract}
The aim of this study is to determine the potential of the IDCS (Sign Language Translation System) developed as a communication environment to support the communication process and academic success. The study was conducted with case study which is one of the qualitative research methods. The study group of the study consists of 11 experts including special education teachers who graduated from hearing impaired teachers, specialist teachers and sign language interpreters. The system was designed considering the deficiencies in the literature and the development process was carried out. After the necessary arrangements, expert opinions about the system were obtained and the collected data were analyzed. The data were collected under two themes: communication processes and academic achievement. When the findings related to the communication processes are analyzed, it is thought that the IDCS has the potential to increase communication performance and socialization mostly. However, it has been said that IDCS has the potential to learn sign language at starter level and increase vocabulary by participants. The effect of IDCS on course work processes is another finding. It has been found that IDCS has the potential to increase communication performance, socialization, vocabulary, academic achievement, sign language learning and interest in sign language learning. It is also among the results that laziness in hearing ability can lead to abstraction.
\end{abstract}

Keywords: Sign language translation system, communication processes, hearing impairment, communication, hearing

\section{Giriş}

İşitme, bireyin çevresiyle etkileşim kurmasını zihinsel, bilişsel, dilsel gibi alanlarda gelişmesini sağlayan önemli bir duyudur (Genç, Ertürk ve Belgin 2005). İşitmenin öğrenme, iletişim ve diğer alanlardaki becerileri engelleyici rol göstermesine ise işitme kaybı denir (Belgin, 2003). İşitme duyusu sayesinde konuşma yetisi gelişebilir, çevredeki olaylar daha iyi algılanabilir ve kelime dağarcığı genişletilebilir. Bu duyunun işlevini kaybetmesi ise anlama ve kavrama güçlüğü yaşanmasına neden olmaktadır (Çiftçi, 2009). 2010 yılında yapılan Özürlülerin Sorun ve Beklentileri Araştırmasına göre kayıtlı engelli nüfus içerisinde, işitme yetersizliği oranı \%5,9 olarak görülmektedir. Milli Eğitim Bakanlığı Özel Eğitim ve Rehberlik Hizmetleri Genel Müdürlüğü'nün 2018-2019 verilerine göre ilkokul, ortaokul ve lise düzeyinde toplamda 3432 öğrenci eğitim görmektedir (MEB, 2018/'19). 2010 y1lında yapılan Özürlülerin Sorun ve Beklentileri araştırmasına göre yetersizliği olan bireylerin $\% 25,6$ 's s eğitim olanaklarının arttırılmasını talep etmektedir. Bu talep doğrultusunda yetersizlik yaşayan bireylerin sessiz çağrısına kulak verilerek onlara yaşadıkları toplumun kültürünü ve dilini anlamaları sağlanmalıdır.

İşiten bireyler bebeklikten itibaren seslere karşı duyarlılık gösterir, sesleri tanır ve beklenen zaman aralıklarında gelişim göstererek (Karacan, 2000) kendi dillerini öğrenebilir. İşiten birey çevresel sesleri ayırt eder, ritim ve tonlamaların farkına varır, işittiği sesleri anlamlandırır bu sayede kelime hazinesini de arttırabilir (Cole, 1992; Akt. Çeliker ve Ege, 2005). Fakat İşitme Yetersizliği Yaşayan (İYY) birey bu deneyimlerden mahrum kaldığı için yetersizlik durumu zamanla sosyal becerilerini de olumsuz yönde etkilemektedir (Kizir ve Tekinaslan, 2016). Bununla birlikte IYY 'lerin dilde yaşadıkları problemler iletişim becerilerini ve akademik 
yaşantılarını da etkilemektedir (Marschark, 2007). Ayrıca IYYY bireyler işiten bireylere nazaran daha az çeşitlilikte öğrenme ortamları ile gelişimlerini gerçekleştirmek zorunda kalmaktadırlar. Sesli materyallerden faydalanamamaları, yazılı ve basılı kaynakları okuma yazmada yaşadıkları sıkıntılardan (Selvi, 2004) dolayı kullanamamaları, işiten bireylere oranla İYY bireylerin okuma yazma öğrenimi daha uzun sürmesi (Paul, 2001) ve eğitim ortamlarında bu bireylere yönelik hazırlanan materyal eksiklikleri (Sarıkaya ve Börekçi, 2016) bireysel gelişimlerini zorlaştırmaktadır.

IYY bireylerin eğitimine yönelik yapılan çalışmalara bakıldı̆̆ında mobil teknolojilerin eğitime entegresinin İYY öğrencilerin öğrenmesinde etkili olduğu ve bilgiye erişimini arttırdığ ortamında kullanılan bilişim teknolojilerinin bireylerin motivasyonunu ve akademik başarılarını arttırdığı da söylenebilir (Dickerson, Williams ve Browning, 2009). Ülkemizde eğitim ortamına baktığımızda her bireyin çeşitli kaynaklara erişimini ve kaynaklardan eşit şekilde faydalanmalarını sağlamak adına bazı gelişmeler görmek mümkündür. Fırsatları Arttırma ve Teknolojiyi İyileştirme Çalışması (FATİH) kapsamında donanım ve yazılım altyapısı, eğitsel e-içeriğin sağlanması ve yönetilmesi, öğretimde etkin bilişim teknolojileri kullanımı, bilinçli, güvenli, yönetilebilir ve ölçülebilir bilişim teknolojilerinin kullanımının sağlanması, öğretim programlarında etkin bilişim teknolojileri kullanımı çalışmaları yapılmıştır. Ülkemizde fırsat eşitliğini sağlamak adına z-kitaplar, e-içerikler, kütüphanelerin sağladığı çeşitli yazılı basılı kaynaklar eğitim öğretimde yararlanılabilecek kaynaklardandır. Bu kaynaklar genellikle engelsiz bireyleri hedef almaktadır. Çeşitli yetersizlikleri bulunan bireyler için aynı çeşitlilik ve zenginlikte içerikler bulunmamaktadır. Benzer durum IYYY bireyler için de geçerli olup IYY bireyler bu imkânlardan ve gelişmelerden yeterli düzeyde yararlanamamaktadır. Alanyazın incelendiğinde IYYY bireyler için çalışmaların azlığı dikkat çekmektedir. Ayrıca hazırlanan kaynak ve materyallerin yeterli olmadığı ve bu bireylerin ihtiyaçlarını gidermede yetersiz olduğu görülmektedir (Demirhan 2008; Keser ve Özdemir, 2017; Sarıkaya ve Börekçi, 2016). Fiziki şartlar ve ailenin ilgisizliği (Sarıkaya ve Börekçi, 2016), kelime dağarcıklarındaki eksiklik (Sarıkaya ve Börekçi, 2016; Keser ve Özdemir, 2017; Çiftçi, 2009), cihaz eksikliği (Sarıkaya ve Börekçi, 2016) karşılaşılan diğer problemler arasındadır. Öğretmenlerin ise işaret dilinde yetersiz olma, okul aile işbirliği gibi noktalarda sıkıntı yaşadığı bilinmektedir (Sarıkaya ve Börekçi, 2016).

IYY bireylerin karşılaştıkları zorlukların başında ise iletişim gelmektedir. İşitme kaybının derecesi önemli olsa da ilerleyen zamanda dilde yaşayacakları problemler sosyal, duygusal ve eğitim alanlarında yetersizlik oluşturabilmekte ve çeşitli zamanlarda olumsuz durumlar olarak karşılarına çıkabilmektedir (Şahlı ve Belgin, 2011). İYY bireyler günlük yaşantılarında işaret dili bilmeyenler ile gerçekleştirdikleri iletişimlerde desteğe ihtiyaç duymaktadırlar. $\mathrm{Bu}$ desteği bulamadiklarında dudak okuyarak veya yazarak iletişim kurmayı tercih etmektedirler. İşiten bireyler de işaret dilini bilmediklerinden dolayı sözlü dili kullanmayan IYYY bireye yazarak anlatmayı tercih etmektedir (Gürboğa ve Kargın, 2003; Yücel, Sennaroğlu ve Belgin, 1996). Bununla birlikte sosyal yaşamda, banka, hastane gibi kurumlarda ve diğer yaşam alanlarında da işlerini halletmekte zorlanmalarından dolayı yardım aldıkları görülmüştür. İletişim kuramama 
problemlerinden dolayı IYY öğrenciler işiten bireylerden ziyade kendisi gibi İYY bireylerle arkadaşlık kurmayı tercih etmektedir (Sarıkaya ve Börekçi, 2016). İletişim problemleri IYY bireylerde içe kapanıklık (Parlak, 2011), toplumdan soyutlanma isteği, sinirli davranışlar sergileme, kurallara uymak istememe gibi davranışları ortaya çıkarmaktadır. (Sarıkaya ve Börekçi, 2016). İletişim problemleri sadece günlük yaşantılarında değil IYYY bireylerin akademik yaşantılarına da olumsuz yönde etki ederek gelişimlerinde çeşitli zorlukları da beraberinde getirmektedir.

IYYY bireylerin günlük yaşantılarında iletişim kurma problemleri yaşadıkları ve bu problemlerin yaşam kalitelerini olumsuz yönde etkilediği aşikârdır. İYY bireylerin günlük yaşantılarında işiten bireylerle daha kolay iletişim kurmalarını sağlamak için çeşitli çözümler düşünülmekte hatta işaret dili öğrenmeyi teşvik edici çalışmalar yapılmaktadır. Bu yaklaşım iletişim problemini gidermek için çözüm yollarından biri olmakla birlikte toplumun tüm bireylerini veya İYY bireylerle iletişim kurma ihtimali olan tüm bireylere erişimin mümkün olmayacağı da ortadadır. Bu noktada iletişim problemini giderecek çözümlerin ortaya koyulması iletişim problemini giderme noktasında etkin sonuçlar doğurabilir.

Spread The Sign projesi birçok ülkenin bir araya geldiği sözlük tabanlı bir projedir. Ancak sistemde her cümle çevirisi yer almamaktadır. Sadece belirlenmiş cümle kalıpları çevrilebilmektedir. Yasan (2014) çalışmasında Türkçe metinleri Türk işaret diline dönüştürme üzerine çalışmıştır. Gerçekleştirdiği çalışmada sisteme girilen metnin TiD gramer yapılarına uygun olarak çevirme algoritmasını oluşturmuştur. Geliştirdiği sistemde öğrencilerin çeviriyi anlama başarısının \%79,4 olarak olduğu görülmüştür. Sistemin akıcılık yönünden ise yeterli seviye olmadığı belirtilmektedir. Çeviriler hızlandığında ise normalden daha hızlı çeviriler yapmaktadır. Geliştirilen yazılımın sadece metinleri yazıya çevirdiği ancak sesleri çevirme özelliğinin yer almadığı görülmektedir. Bir diğer yazılım ise Transcense' dir. Uygulamada konuşma sesleri akıllı telefon ekranına metin olarak yazılmaktadır. Her ses ayrı algılanarak ayrı renklerde yazılması da İYY bireyin kimin konuştuğunu anlamasına yardımcı olacak bir özelliktir. Bu durum IYY bireylerin sosyal yaşantılarında anında cevap vermeye veya ortamda geçen konuşmayı anlamalarında kolaylık sağlamaktadır. Yazılımda İngilizce cümleler 3 boyutlu bir model aracılığıyla işaret diline çevrilebilmektedir. Ditcharoen, Naruedomkul ve Cercone (2010) yapmış oldukları çalışmada SignMT'yi hayata geçirmişlerdir. Çevresel yazılı, basılı kaynaklardaki cümleleri işaret diline çevirmektedir. Sözdizimi ve anlamsal farklılıklar dikkate alınmıştır. SignMT öğrencilerin öğretmene bağımlılıklarını azaltacak ve kendi dillerinde öğrenmelerine katkı sağlayacak şeklinde tasarlanmıştır. Ders kitapları, karikatürler gibi farklı kaynaklardaki cümleleri çevirme özelliğine sahiptir. Aracın doğruluk oranı ve kullanıcı memnuniyet düzeyi yüksek çıkmıştır. İYY öğrencilerin ilgi alanlarını ve motivasyonlarını arttırmada, temel becerileri geliştirmede ve öğrenme sürecinde yarar sağlayacağı görülmüştür. Bu bireylerde teknoloji kullanımı normal bireyler kadar başarılı ve sık zaman aralıklarında olmasa da İY bireylerin teknoloji ile etkileşimlerinin geliştirilebilir düzeyde başarılı olduğu ve teknoloji kullanılarak farklı eğitimler verilebileceği sonucu çıkarılabilmektedir. Fang, Gao ve Zhao'nun sensörlü eldiven kullanarak geliştirmiş oldukları çalışmada, 5000 işaretin arasından bir işaretin tanınma süresini yarım saniyenin altına düşürerek \%83 başarı elde etmişlerdir. SignAloud yazllımda ise bir eldiven aracilı̆ıyla işaret dili sesli olarak 
çevrilebilmektedir. Ancak bu uygulamayı kullanmak için bilgisayar ve eldivenin bireyin yanında bulunması gerekmektedir.

Dünya çapında veya ülkelerin özelinde İYY bireylere yönelik geliştirilmiş olan sözlükler, çeviri sayfaları veya çeşitli çoklu ortam bileşenleri mevcuttur. Mevcut yazılımlar incelendiğinde yurt dışında yayınlanan birçok yazılımın Türkçe'ye dil desteğinin bulunmaması bu yazılımlardan yararlanma ihtimalini azaltmaktadır. Bununla birlikte ülkemizde geliştirilen yazılımlar incelendiğinde sözlük niteliği taşıyan yazılımların varlığı dikkat çekmektedir. Bu tür işaret dili sözlük çalışmalarının, daha çok bir kelimenin işaret dilindeki karşılığıyla eşleştirilmesi şeklinde oluşturulmuştur. Ayrıca işaret dilini Türkçe'ye çeviren yazılımlarla ilgili çeşitli robot çalışmaların varlığının yeterli düzeyde olmadığı görülmektedir. Bu durumlar belirli bir düzeyde iletişime imkân verirken etkili bir iletişim kurmaya imkân tanıyamamaktadır. Bu noktada işaret dilinin yapısı, dilimizdeki eklerin işaret dilinde kullanılmaması, yöresel ve bölgesel olarak işaret dilinin farklılık göstermesi gibi durumlar da sistemlerin etkinlik düzeyini daha da azaltmaktadır.

IYY bireylerin günlük yaşantılarında ihtiyaç duydukları iletişimi sağlayan, kültürel özelliklerimizi dikkate alan bir ortamın oluşturulması iletişim problemlerini gidermede yardımcı olacaktır. Bu bakış açısı ile geliştirilen çözümlerin kullanılabilir olması, etkin sonuçlar elde edilebilmesi ve hem günlük yaşantı hem de akademik yaşantılarında gelişimlerine destek olması açısından çalışma önemli katkı sağlama potansiyeline sahiptir. Geliştirilecek çözümlere 1şık tutma, etkinliğini artırma, farklılıklara göre tasarım yapabilme gibi yaşantıları odağa alan ve uzmanların sistem tasarımına yönelik görüşlerinin ortaya koyulması ülkemizde IYYY bireylerin yaşamış olduğu iletişim problemlerini gidermeye katkı sağlayacaktır.

\section{Araştırmanın Amacı}

Bu çalışmanın amacı, iletişim ortamı olarak prototip geliştirilen İDÇS (İşaret Dili Çeviri Sistemi)'nin iletişim sürecini ve akademik başarıyı destekleme potansiyeline yönelik katılımcı görüşlerini belirlemektir. Bu kapsamda şu araştırma sorulara cevap aranacaktır:

1. Geliştirilen IDÇS'ye yönelik uzman görüşleri nelerdir?

a. Geliştirilen İÇS'nin bireylerin iletişim sürecine etki potansiyeli hakkındaki uzman görüşleri nelerdir?

b. Geliştirilen İDÇS'nin İYY öğrencilerin akademik başarılarına etki potansiyeli hakkında uzman görüşleri nelerdir?

\section{Araştırmanın Sınırlılıkları}

Bu çalışma sonuçları 11 katılımcı görüşü ile sınırlıdır.

\section{Yöntem}

$\mathrm{Bu}$ çalışmada nitel araştırma yöntemi tercih edilmiş ve İDÇS'nin gelişim süreci ve alınan uzman görüşleri durum olarak değerlendirilmiştir. Öncelikli olarak İDÇS'nin geliştirilmesi yoluna gidilmiş ve sonrasında İÇS'nin iletişim sürecini ve akademik başarıyı destekleme potansiyelini belirlenmesi için uzman görüşleri alınmıştır. Çalışmada nitel araştırmanın tercih edilmesinin nedeni bir durum, olgu ve ya algıların kendi doğal ortamında derinlemesine araştırılmasının (Yıldırım ve Şimşek, 2008) istenmesidir. Nitel araştırmalarda az sayıda katılımcı ile görüşerek çok fazla 
derinlemesine alınan bilgiler araştırmacıya bu bilgilerin algılanması, yorumlaması ve analizinde katkı sağlamaktadır (Yıldırım, 1999). Durum çalışmasında ise bir problem seçilerek bu problem etrafında örneklemek için durum sınırlandırılır ve örnek durum derinlemesine incelenir. Belirlenen bir sorun hakkında bir genelleme üzerinde yeniden durmak ve bir durum hakkında fikir geliştirmek için yapılır (Merriam, 2013). Bu çalışmada da İDÇS'nin etki potansiyeline yönelik uzman görüşlerinin açı̆̆a çıkarılmasının istenmesinden dolayı da durum çalışması ile sürdürülmüştür.

\section{Çalışma Grubu}

Çalışma grubunun oluşturulmasında IYY bireylerle geçirdikleri zamanların, yaşantılarının fazla olmasına dikkat edilmiştir. Öncelikle çalışma grubundaki bireylerle iletişime geçilmiş ve deneyim yılları, yaşantıları, gönüllükleri hakkında bilgiler alınmıştır. Amaçlı örnekleme yöntemi ile maksimum örnekleme yöntemi bir arada kullanılmıştır. Ulaşılabilir olan 18 uzman ile görüşme yapılarak bu doğrultuda IDÇS'yi incelemeye ve bu alanda görüşlerini belirtmeye istekli bireyler arasından seçilen 11 kişi çalışma grubuna dâhil edilmiştir.

Tablo 1

Çalışma Grubunda Yer Alan Katılımo Özellikleri

\begin{tabular}{|c|c|c|c|c|}
\hline Katılımcilar & Cinsiyet & Uzmanlık Alanı/Mesleği & $\begin{array}{l}\text { Tecrübe } \\
(\text { Yil) }\end{array}$ & Görev Yaptı̆̆ı İl \\
\hline (K1) & Erkek & İşitme engelliler/Özel Eğitim Öğretmeni & 6 & Tokat \\
\hline (K2) & Kadin & İşitme engelliler/Özel Eğitim Öğretmeni & 1 & Kahramanmaraş \\
\hline (K3) & Kadin & Yeminli İşaret Dili Tercümanı/Öğretmen & 5 & Kahramanmaraş \\
\hline (K4) & Erkek & İşitme engelliler/Özel Eğitim Öğretmeni & 4,5 & Kocaeli \\
\hline (K5) & Kadın & İşitme engelliler/Özel Eğitim Öğretmeni & 12 & Samsun \\
\hline (K6) & Kadin & İşitme Engelliler/Uzman Öğretici & 3,5 & İzmir \\
\hline (K7) & Kadin & İşitme engelliler/Özel Eğitim Öğretmeni & 7 & Manisa \\
\hline (K8) & Erkek & İşitme engelliler-İşaret Dili & 5 & Manisa \\
\hline (K9) & Kadın & $\begin{array}{l}\text { Tercümanı/Özel Eğitim Öğretmeni } \\
\text { İsitme engelliler/Özel Ĕ̆itim Öğretmeni }\end{array}$ & 13 & Kahramanmaras \\
\hline (K10) & Kadin & İsitme engelliler/Özel Eğitim Öğretmeni & 13 & Hatay \\
\hline (K11) & Erkek & $\begin{array}{l}\text { Yeminli İşaret dili tercümanı/İşaret Dili } \\
\text { Eğitmeni }\end{array}$ & 8 & Ankara \\
\hline
\end{tabular}

\section{Veri Toplama Araçları}

Araştırmada yarı yapılandırılmış görüşme formu uygulanmıştır. Görüşme formunda yer alan soruların kolay anlaşılır ve açık uçlu olmasına dikkat edilmiş katılımcıyı yönlendiren sorulardan kaçınılmış, belirli bir mantığı takip edecek sıralamada sorular hazırlanmıştır. Yarı yapılandırılmış görüşme formu kapsamında;

- IDÇS'nin işiten ve İYY birey arasındaki iletişim sürecine etkisi,

- İşaret dili öğrenimine yönelik etkileri,

- Öğrenme yaşantılarına yönelik etkileri,

- Akademik süreçlere etkileri,

- Öğrenme sürecinde kullandığ1 kaynaklar, içerikler ve ortamlar ile gerçekleştirdikleri iletişime etkileri,

- IDÇS'nin avantajları,

- İÇS'nin dezavantajlarına yönelik sorular sorulmuştur. 
IDÇS'nin tasarlanması, geliştirilmesi ve uygulama süreci. Öncelikle alanyazın taraması gerçekleştirilmiş ve problem tespiti yapılmıştır. Alanyazında IYYY bireylerle işiten bireyler arasında iletişimi arttırmada sesin işaret diline çevrilmesinin yararlı olacağı da önerilmektedir (Demirhan, 2008). Bu doğrultuda konuşma ve yazıyı işaret dilini çeviren bir sistemin geliştirilmesinin önemli olduğu görülmektedir. Sistem alanyazında ki eksiklikler düşünülerek tasarlanmış ve sonrasında geliştirme sürecine gidilerek veri tabanı oluşturulmuştur.

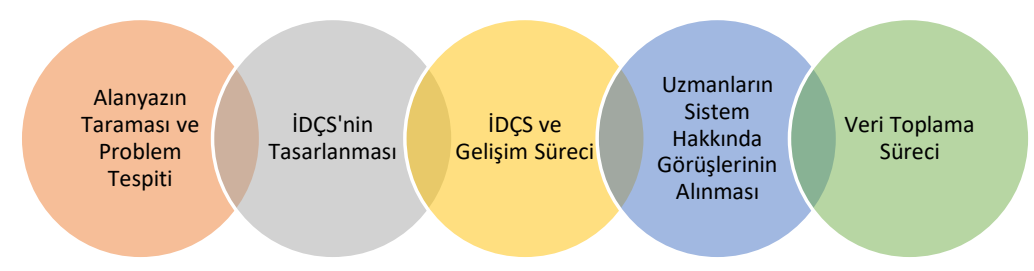

Şekil 1. Uygulama sürecinin aşamaları

İDÇS, "İşaret Dili Çeviri Sistemi" kelimelerinin baş harflerinden oluşmaktadır. Sistem web üzerinden ve mobil cihazların kullanımı için uygundur. IDÇS'de işitme engelliler okulunda kullanılan ve IYYY bireyler tarafından çekilmiş hazır videolar kullanılmıştır. Videolarda bir hareketin birden fazla tekrarı mevcuttur ve video süreleri ortalama 30 sn.dir. Videolarda akıcılığı sağlamak adına tekrarlardan oluşan kelimeler kesilmiş ve sadece bir hareketi gösterecek şekilde düzenlenmiştir. Bununla birlikte mümkün olduğunca videolarda tek hareketin bulunduğu aralık seçilmiştir. Aynı zamanda kelimeye ait görselin ve dudak hareketinin videoda olduğu süre aralığının da bu süreye denk gelmesi öncelikli olarak tercih edilmiştir. Çünkü IYYY bireylerde anlaşılmayan kelimelerde görsellik oldukça önemlidir (Mayberry ve Squires, 2006) ve anlayamadıklarında yazarak ve dudak okuma yöntemini kullanarak iletişime geçmeye çalıştıkları bilinmektedir (Gürboğa ve Kargın, 2003; Yücel, Sennaroğlu ve Belgin, 1996). İletişimde akıcılığı sağlamak adına ise video süreleri kısa tutulmuştur. İDÇS' nin veri tabanında 1489 kelime işareti yer almaktadır. Yüklenen kelimelerden işaretleri aynı olanlarla eşleştirilmesi sonucunda kelime sayısı 1550 civarında olmaktadır.

Araştırmacı, süreç içerisinde işitme engelliler öğretmeni tarafından verilen işaret dili eğitimini almıştır. Eğitim süresince aynı zamanda işitme engelliler öğretmeniyle geliştirilmesi planlanan sistem hakkında görüşme imkânı elde etmiştir. Eğitmen ile yaptığı ikili görüşmeler ve gerçekleştirilen alanyazın taraması neticesinde gerekli düzenlemeler sağlanmış ve sonrasında sistemle ilgili uzman görüşleri alınmıştır. Konuşma ve metin çevirisini sağlayan aynı zamanda basılı materyal, metin çevirme ve işaret diline çevrilen metni video olarak bilgisayara indiren web tabanlı prototip İDÇS oluşturulmuştur. 


\section{IŞARET DILI ÇEVIRI SISTEMI}

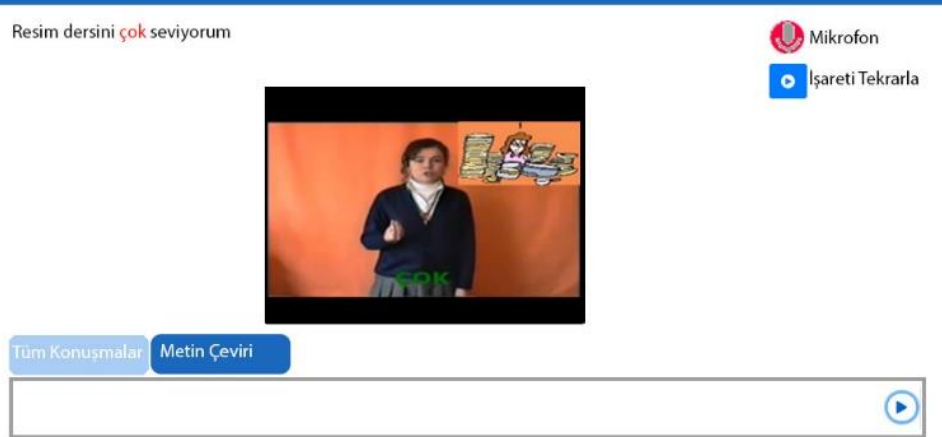

Şekil 2. İşaret dili çeviri sistemi arayüzü

Sistemle ilgili gönüllü bir öğretim üyesi, bir öğretim görevlisi ve bir işitme engelli öğretmeni iletişime geçilerek pilot görüşme gerçekleştirilmiştir. Alınan görüşler doğrultusunda sistemsel eksikliklerin düzeltilmesi yoluna gidilmiştir. Web tabanlı oluşturulmak istenmesindeki amaç erişimini kolaylaştırmak ve mobil üzerinden kullanımına da imkân vermeyi sağlamaktır. İDÇS'de yer alan özellikleri kısaca şu şekilde sıralamak mümkündür:

- Basılı kaynaklarının yüklenerek işaret diline tercümesinin yapılması,

- Konuşma sesinin işaret diline tercüme edilmesi,

- Metin girişlerinin işaret diline tercümesinin yapılması,

- Konuşmalarda gözden kaçan ve anlaşılmayan yerlerin tekrarına imkân vermesi

- Konuşma seslerinin metinsel geçmişini görmeye imkân vermesi,

- Veri tabanında yer almayan kelime videolarının parmak alfabesinde çevirisinin yapılarak kesintisiz iletişimi sağlaması,

- Yüklenen metin temelli kaynakların işaret dili çevirisinin video olarak bilgisayara indirilmesinin ve istenildiğinde tekrarına sağlanması,

- Yazılı metinler arasına bekleme sürelerinin eklenebilmesi ve bu sayede cümleler arası geçişlerde, paragraf aralarında ve konuşmalarda doğru çevirinin sağlanması adına belirlenen süre kadar İDÇS'nin çeviriyi bekletmesi

IDÇS'nin arka planda yer alan akış şeması aşağıda yer almaktadır (bkz. Şekil 3). 


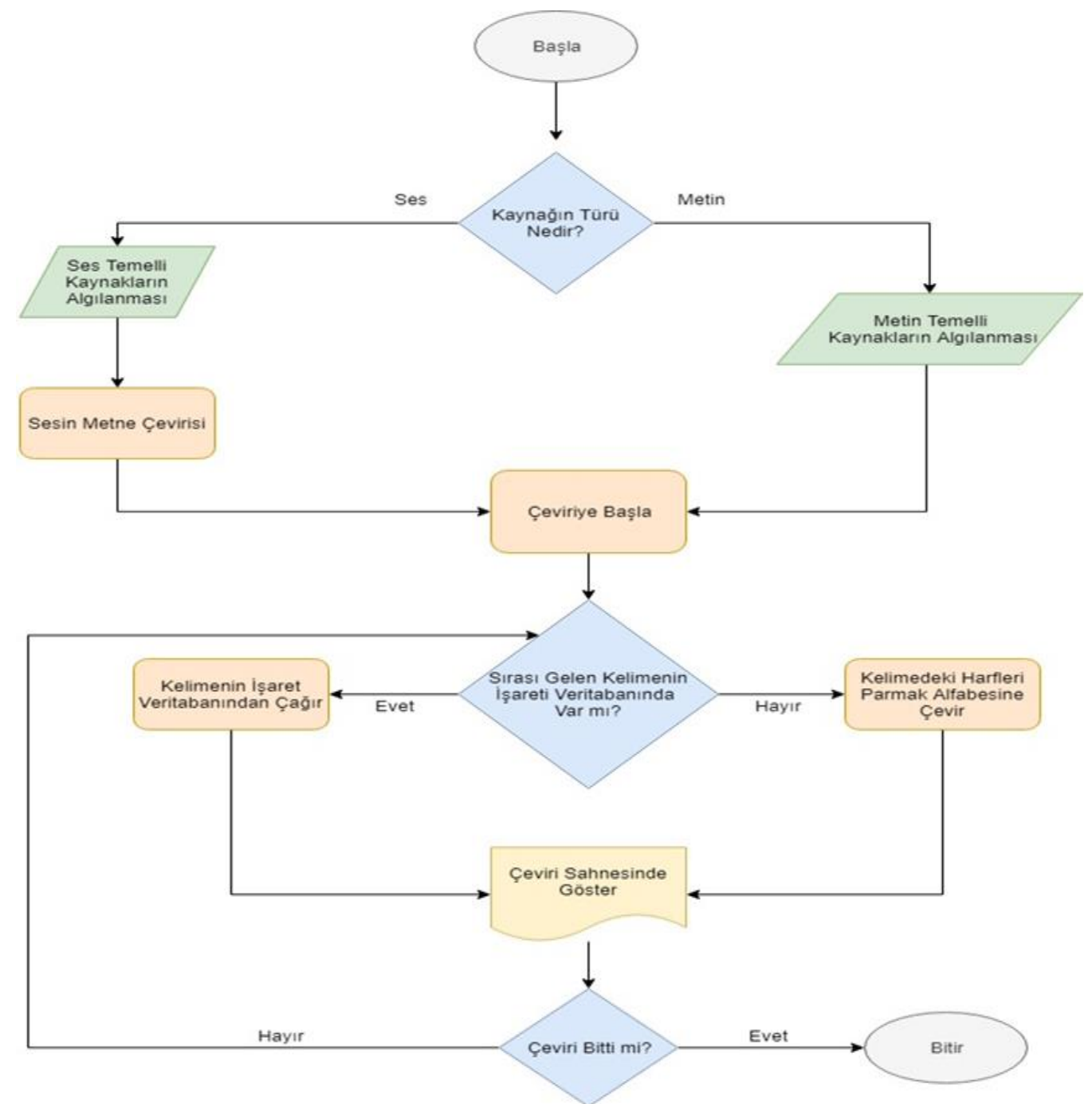

Şekil 3. İDÇS akış şeması

\section{Verilerin Analizi}

Çalışma kapsamında toplanan veriler içerik analizi yöntemi kullanılarak analiz edilmiştir. İçerik analizinde benzer veriler; belirlenen kavramlar ve temalar çerçevesinde bir araya getirilerek yorumlanmaktadır (Yıldırım ve Şimşek, 2008). Görüşme sonucunda elde edilen 195 dakikalık ses kayıtları dinlenerek 48 sayfalık veri elde edilmiştir. Görüşmeler ortalama 17 dk. sürmüştür. Maxqda 2018 programına geçilerek analiz edilmiştir. Veriler detaylı bir şekilde araştırma amacı dikkate alınarak okunmuş ve anlamlı ifadeler işaretlenerek kodlanmış ve kodlanan verilerden anlamlı ifadeler oluşturulmuştur. Araştırma soruları ile ilişkilendirilen bulgular birbirini destekleyecek nitelikte gruplandırılmıştır. Bu yöntem tekrar tekrar yapılarak kategori ve temalar belirlenmiştir. Veri toplama aracının geçerliği ve güvenilirliği ile ilgili aşağıdaki önlemler alınmıştır.

- Görüşme ve gözlemlerin detaylı kayıtları

- Veri toplama aracının uzmanlar tarafından kontrolü

- Araştırma sorularının araştırmanın amacını kapsaması

- Veri toplama araçlarının dil uzmanı tarafından kontrolü 


\section{Araştırmanın Geçerliği ve Güvenirliği}

Araştırmacı araştırmanın geçerliliğini sağlamak adına,

- Verilerin tutarlılı̆̆ını sağlamak amacıyla nitel araştırma üzerine çalışma yapmış iki ayrı uzmandan yardım alınmıştır.

- Gönüllü katılımcılar tercih edilmiştir.

- Araştırmacı esnekliği sağlanmıştır.

- Yapılan görüşmeler kaydedilmiştir.

- Veri analizinin tutarlılığını sağlamak adına uzman kontrolünün sağlanmıştır.

\section{Bulgular}

IDÇS'ye yönelik görüşler iki ayrı tema altında toplanmıştır. Her temanın altında kategoriler ve bu kategorilerin altında kodları sunulmuştur. Elde edilen bulgular tema ve kategori başlıkları altında verilmiştir.

\section{İletişim Süreçleri}

İletişim süreçleri teması, İYY bireylerin işitme yetisine sahip bireyler ile olan iletişim süreçlerindeki durumu ve işaret dilini kullanma performansına yönelik bulguları kapsamaktadır. İDÇS'nin "İletişim Süreçleri” temas1 "Çevre İle İletişim" ve "İşaret Dili Öğrenimi" olmak üzere iki ayrı kategori altında toplanmıştır.

Tablo 2

İletişim Süreçleri Temasına Yönelik Sunulan Betimsel Veriler

\begin{tabular}{llll}
\hline Kategori & Kodlar & N & $f$ \\
\hline Çevre ile iletişim & İletişim Performansı & & \\
& \multicolumn{1}{c}{ Olumlu Etki Boyutu } & 9 & 25 \\
& \multicolumn{1}{c}{ Düşük İletişim Hızı Boyutu } & 2 & 4 \\
\cline { 2 - 5 } & Sosyalleşme & 7 & 14 \\
& İşitme Yetisinde Tembellik & 3 & 9 \\
\hline İşaret Dili Öğrenimi & Başlangıç Seviyesinde Öğrenme & 11 & 14 \\
& Kelime Dağarcı̆̆ına Etki & 11 & 12 \\
& Uzmanların İDÇS'yi Kullanma Durumu & 7 & 8 \\
& İşaret Dilini Öğrenme İlgisi & 3 & 4 \\
\hline
\end{tabular}

Çevre ile iletişim süreçleri kategorisi altında yer alan ilk kod "İletişim Performansı" dır. İletişim performansı, IYY bireylerin sosyal yaşam alanlarında işiten bireylerle gerçekleştirdikleri iletişim süreçlerine yönelik görüşleri içermektedir. İletişim performansı kodunun altında yer alan ilk boyut "olumlu etki boyutu" dur. Bu boyutta İDÇS ile kurulan iletişimlerde sistemin iletişimi olumlu yönde etkilemesine yönelik görüşler yer almaktadır. Katılımcılar İYY bireylerin çevre ile kurdukları iletişimde İÇS'nin işaret dili bilmeyenler ile iletişime geçme potansiyelinin olduğunu düşünmektedirler. Ayrıca İDÇS sisteminin işaret dili bilmeyenlerle iletişimde kolaylaştırıcı etkilerinin olabileceği katılımcılar tarafından yoğun bir şekilde vurgulanmıştır. İletişim performansına yönelik örnek katılımcı görüşleri şöyledir; "Çevreyle etkileşime olumlu etkisi olabileceğini düşünüyorum. Bu çocuklarm sinıfta arkadaş çevresi hatta ailesi bile işaret dili bilecek çocuklarn ama mahalledeki herkes işaret dilini bilmeyecek. İşte burada etkileşim açısından bu program çok önemli."(K8). "Çok harika olur. İşitme engelliler bu konuda çok büyük problemler yaşıyor. Noterde adliyede ondan sonra tapuda 
her yerde işaret dili tercümanına ihtiyaç var. Böyle bir sistem olduğunda her yerde olduğunu düşünelim. Bankaya gittiğinde böyle bir sistemle karşılaşsa derdini dile getirebilse veya karşıdakinin ne dediğini anlasa oradaki sistemden çok çok güzel olur. Her an biz yetişemiyoruz her yere yani küçük yerlerde veya başka bir yerde o anda müsait olmayabiliyor insan ama işitme engelli orada işini halletmesi gerekiyor ben müsait değilsem bir buçuk saat orada beni beklemek zorunda kalıyor. O yönden onlara faydası dokunabilir."(K3). "Çevre ile iletişim süreçlerini tabi ki de etkiler. Sistemde söylenilen kelimelerin karşılıklarının yer alması bu şekilde anlatılamaya çalışılması gayet önemli. Birey kendi derdini bu yolla kısaca anlatabilir." (K10). "Kendilerini ifade edemeyince kötüde hissedebiliyorlar hani toplumdan uzaklaşabiliyorlar bu sistemle toplumun içine karışabilirler. Toplumla iletişim kurabilirler. Kendilerini daha iyi ifade edebilirler." (K6).

İletişim performansı kodunun altında yer alan bir diğer boyut ise "düşük iletişim hızı boyutu "dur. Düşük iletişim hızı boyutu, işaret dili bilen bireylerle İYY bireylerin iletişimine kıyasla işiten ve IYY birey arasındaki iletişimde İDÇS'nin normalden yavaş kalacağına yönelik elde edilen bulguları kapsamaktadır. 2 katılımcı IYY bireylerin işaret dili ile hızlı bir iletişim gerçekleştirdiklerini ve İDÇS gibi çeviri sistemlerinin işaret dili iletişimine göre yavaş olduğunu belirterek IYY bireylerin bu sistemleri kullanımları esnasında düşük iletişim hızı oluşturabileceğini ifade etmektedirler. Katılımcılar İÇS'de olduğu gibi kelimelerin işaret karşılıklarının tek tek gelmesinin bu bireyler açısından sıkıcı olabileceğini ve muhtemelen çevirilerin yavaş algılanabileceğini düşünmektedir. Bu nedenle İYY'lerin iletişimi yarıda bırakabilecekleri ve kullanmak istemeyebileceklerini ifade etmişlerdir. Düşük iletişim hızı boyutu ile ilgili katılımcı görüşleri şu şekildedir;

"İşaret diliyle işitme engelli bir bireyle konuşmak daha kolaydır. Insanlar için araya program koyduğumuz zaman iletişimi yavaşlatıyor bu da işitme engelli bireyler nasıl ki işaret dili bilmeme rağmen yavaş işaret dili kullandiğım için ya da bütün işaretleri yapmaya çalıştığım için konuşmayı bırakıp gidiyorlarsa araya program koyduğumuz zamanda sıkılıp gitmek isteyebilirler. Kullanmak istemeyebilirler. İletişimi yavaşlattığı için." (K1). "Çevre ile iletişim sürecine etki edebilir ama sistem biraz yavaş kalabilir." (K7)

İletişim performansından sonra en çok sosyalleşme kodu vurgulanmıştır. Katılımcılar İDÇS'nin IYY'lerin işiten bireylerin söylediklerini anlamaları ve bu yolla kendilerini ifade etmelerine olanak tanımasından dolayı sosyalliklerinin ve çevre ile iletişimi arttırıcı potansiyelinin olduğunu vurgulamışlardır. Ayrıca İDÇS'nin kendini ifade eden İYY bireylerin özgüvenini arttırıcı ve toplumda kabul görmesini sağlayıc1 potansiyelinin bulunduğu elde edilen bulgular arasındadır. Sosyalleşmeye koduyla ilgili bazı katılımcı görüşleri şu şekildedir:

"Kendini ifade eden birey kendini güvende hisseder. Böyle olmadiğı zaman çocuk kendisini yetersiz hisseder. İşaret dili de olmazsa işitme engelli bireyler kendilerini yetersiz hissedip kötü hisseder. Uzaklaşır toplumdan. Bu şekilde düşünüyorum." (K6). "Çevre etkileşimi ne kadar fazla olursa toplumsal uyum becerileri artar." (K8). "Çocuk kendini ifade edebilir. Kendini geliştirebilir. Sosyalleşmesi artabilir. Kendi işini kendi görebilir hale gelebilir bu avantajlı noktalarn diyebiliriz." (K10)

İşitme yetisinin tembellik kodu, katılımcı görüşleri doğrultusunda işaret dili kullanımının IYYY bireylerin var olan işitme duyusunun gelişmesini ve dolayısıyla konuşma yeteneğinin olumsuz etkileneceği yönündeki görüşleri içermektedir. 3 katılımcıya göre işaret dili kullanma IYYY bireyler için daha kolay olduğundan bireyler kendini zorlamayarak dudak okuma ve işaret dili kullanmaya yönelecektir. Birey 
kendini konuşmaya ve duymaya zorlamadığından dolayı da işitme duyusunda tembellik oluşacağı katılımcılar tarafından belirtilmiştir. Bununla birlikte İDÇS kullanımıyla işitme duyularında meydana gelecek tembelliğin bu bireylerin çevre ile iletişimini daha da zayıflatacağı düşünülmektedir. İşitme yetisinde tembellik koduna yönelik bazı katılımcı görüşleri şu şekildedir:

"İşitme yetisi az olan bir bireyde mesela işaret dili kullandiğında bu çocuk dudak okumaya işaret diline yöneldiğinde az da olsa duyuların kaybediyor. Çünkü algısın tembelleştiriyor. Dudak okumaya işaret dilini kullanmaya yöneliyor. İşitme duyusunu birey tembelleştirebiliyor." (K6). "İşitmeyen çocuklarn tamamen işaret dili kullanmaya yönlendirir. Çünkü işaret dilini kullanma kolaylı̆̆ı vardır. O nedenle işiten ve işaret dili bilmeyen bireylerle iletişimlerini zorlaştırabilir tamamen işaret kullanma. Konuşmaya yönelik çalışmalarında tembelleştirebilir onları." (K7). "Soyutlayabilir. Şu şekilde toplumda hani işaret dili kullanıldıkça kendi dünyalarnna çekilirler Bizim anadilimiz Türkçedir Türkçe konuşuyoruz değil mi bunlar Türkçe konuşamayacaklardır. Kendilerini konuşmaya zorlamayacaklardır. Belki elma demek olduğunu biliyor ama uygulamaya dökmeyi bilmiyor ama bunu işaret dilinde biliyor. Bu sefer karşı tarafa elmayı elma olarak anlatamayacak. Bu her koşulda avantaj olamayabilir. Bu vb. kısıtlamalarda olabilir." (K9).

İşaret dili öğrenimi kategorisinin altında en çok vurgulanan kod "Başlangıç Seviyesinde Öğrenme"dir. Başlangıç seviyesinde öğrenme, kelimelerin işaret dilindeki karşılıklarının öğrenilmesi ve öğrenilen bu kelimelerle basit cümleler kurulması sonucunda karşılıklı iletişimin ilk adımı olarak tanımlanabilir. Bulgular incelendiğinde işiten bireylerin günlük yaşamlarında ihtiyaç duydukları iletişimi ve işaret dili öğrenmeyi İÇS'nin başlangıç düzeyde sağlayabilecek potansiyelinin bulunduğu tüm katılımcılar tarafından yoğun bir şekilde vurgulanmıştır. Başlangıç seviyesinde öğrenme koduna yönelik katılımcı görüşleri şu şekildedir:

"Öğretir. Çok rahat öğretir. Hiç işaret dili bilmeyen bir birey o programın başına geçsin her kelimenin zaten karşılı̆̆ı vardl. Ben inceledim. Kesinlikle çok kolay öğrenir. Sadece cümle kurmada yetersiz kalabilir. $O$ da biraz pratik ister. İşitme engelliler zaman geçirdikçe pratik kazanabilir. Sadece o kelimelerin karşılı̆̆ını öğrenir ama uygulamada pratiklik gerekir. Onu biz bile hani zaman zaman unutabiliyoruz." (K9) "Öğretir. Siz cümle kurarsını o çevirir. Doğrudan gramer yapısına uygun olmayabilir belki ama öğrenmeye yetebilir. Çünkü söylenilenlerin karşılı̆̆ı var sisteminizde. Başlangıç seviyesinde öğrenmelerine yardımc olabilir" (K10). "Bu programla birlikte başlangıç seviyesinde bir işaret dili öğrenebilirsin mesela." (K8).

İşaret dili öğrenimi kategorisinde oluşturulan kodlardan diğeri "Kelime Dağarcığına Etki"dir. Kelime dağarcı̆̆ının gelişimi işaret dili öğrenmenin temelini oluşturmaktadır. İÇS kullanımının işiten ve IYYY bireylerin kelime dağarcı̆̆ını arttırıcı potansiyelinin bulunduğu katılımcılar tarafından ifade edilmiştir. Sistemi kullandıkça kelimelere karşılık gelen işaretleri görmenin kelime öğrenimlerine katkı sağlayacağı katılımcıların tamamı tarafından vurgulanmıştır. Bununla ilgili uzman görüşleri şu şekildedir:

"Cümle yapıları olmasa da kelimeler öğrenilebilir. İlerleyen yaşlardakiler için avantaj să̆layabilir." (K3). "Bence kelime dă̆arcı̆ğın arttırabilir ama bunu cümleye aktarmada belki sikıntı olabilir ama kelime için iyi bir sistem." (K6) "Evet kelime dă̆arciğını da tabi ki etkileyecektir."(K2). "Kesinlikle kelime dă̆arcı̆̆ını arttırabilir. Hatta ben şey de gördüm ekler falanda vardı sanki geldiler gibi çevirilerde rastladım. İşaret dilinde ekler yok ama jest ve mimiklerle anlatmaya çalışıyoruz." (K9). "Kelime dağarcı̆̆ın tabi ki de arttıracaktır. Çünkü 
bahsettiğim gibi öğrenci bu sistem üzerinden kullandikça hem kendi kelime dağarcı̆̆ımı geliştirecek hem de işaret dili öğrenmeye çalışan birey kendini geliştirecek."(K10).

İşaret dili öğrenimi kategorisi altında katılımcıların işaret dili öğreniminde kendilerine de katkı sağlayacağını belirtmesinden dolayı "Uzmanların İDÇS'yi Kullanma Durumu" kodu oluşturulmuştur. 7 katılımcı işaret dilinin üniversitelerde öğretilmemesinden dolayı lisans döneminde işaret dilini öğrenemediklerini ifade etmiştir. Bununla birlikte üniversite sonrasında bu katılımcılar işitme engeli olan öğrencilerle karşılaştıklarında işaret diline ihtiyaç duyduklarını belirtmişlerdir. Bu konuda sistemin İÇS'nin kendilerinin işaret dili öğreniminde olumlu etki potansiyeli sağlayacağı katılımcılar tarafından yoğun bir şekilde ifade edilmiştir. Katılımcıların öğrencilerle iletişimde işaret dili kullanma durumu ile ilgili katılımcı görüşleri Şu şekildedir:

"Bu konuda da işitme engelli öğretmenliğini okuyan öğrencilere de faydalı olacağım düşünüyorum. En azından öğrencilerden birebir öğrenmek zorunda kalmayacaklar atandıklarn yere donanıml gideceklerdir." (K5)

İşaret dili öğrenimi kategorisi altında ele alınan bir diğer kategori ise "İşaret Dilini Öğrenme İlgisi" dir. İşaret dili öğrenme ilgisi kodu son zamanlarda bu yönde toplumda ilgi artışının ve bu ilgiye yönelikte işiten bireylerin İDÇS üzerinden işaret dilini öğrenmeye başlayabileceklerine yönelik bulguları içermektedir. 3 katılımcı işaret dili öğrenmeye yönelik toplumsal bir ilgi olduğunu ve işiten bireylerin ilgisini çekebileceğini vurgulamıştır. Katılımcılar işaret dili öğrenme isteğinin günümüzde popüler bir hal aldığını ifade etmiş ve bu popülerlikten yola çıkarak sistemin işaret dilini öğrenmeye yardımcı olabilecek potansiyelinin olabileceğini ifade etmişlerdir. IDÇS'nin işiten bireylerin ilgilerini bu yöne çekme ve işaret dili öğretebilecek potansiyelinin bulunduğuna değinilmiştir. İşaret dilini öğrenme ilgisi koduna yönelik bazı katılımcı görüşleri şu şekildedir:

"Işaret dili böyle normal insanlar tarafindan cazip bir dil gibi görülüyor hocam benim gözlemlediğim kadarlyla. O yüzden bu sitede ona hizmet edeceği düşüncesindeyim. Sistem merak uyandırıyor insanlarda. Insanlar böyle bir sistemin varlı̆̆ından haberdar olduklarında da girip incelemek isteyeceklerini düşünüyorum. Yani tercih edilecek bir sistem bence."(K5) "İsiten bireylerin işaret dili belki de merak uyandiracak bu program sayesinde. Sistemde gördükçe ögrenme isteklerini de arttıracaktır." (K2). "İşaret dili bilmek popüler hal alabiliyor. Tabi bu işaret dili bilmek için değil de işaret dili biliyorum demek havali geldiği için öğrenmek istiyorlar. Keşke öyle bile olsa öğrensinler yani hiç önemli değil. Öğrenmek isteyen insanlarm kurs bulması sikıntı oluyor bulduğu kurslarn maddi durumları olabiliyor. Böyle bir programla mesela insanlar indirip bilgisayarına yeri geldikçe bir iki göz gezdirip bir şey öğrenebilir..." (K8)

\begin{abstract}
Akademik Başarı
Akademik başarı teması, IYY bireylerin çevresel yazılı, basılı, sesli kaynaklarla ve işiten bireylerle iletişiminin öğrenme yaşantılarına etki potansiyeline yönelik katılımcıların görüşlerini içeren bulguları kapsamaktadır. Akademik başarı teması altındaki bulgular "Bireysel Süreçler" ve "Öğrenme Süreçleri" kategorileri altında toplanmıştır.
\end{abstract}


Tablo 3

Akademik Başarı Teması Altında Yer Alan Betimsel Veriler

\begin{tabular}{|c|c|c|c|}
\hline Kategori & Kod & N(Kişi Sayısı) & f(frekans) \\
\hline Bireysel Süreçler & $\begin{array}{c}\text { Ders Dişı Bireysel Öğrenme Süreçleri } \\
\text { - Ödevler (araştırma vs.) Boyutu } \\
\text { - Ders Çalışma Süresi Boyutu }\end{array}$ & $\begin{array}{l}6 \\
4\end{array}$ & $\begin{array}{l}10 \\
4\end{array}$ \\
\hline Öğrenme Süreçleri & 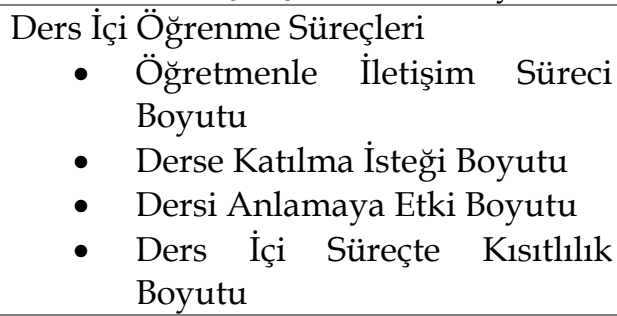 & $\begin{array}{l}5 \\
2 \\
2 \\
2\end{array}$ & $\begin{array}{l}6 \\
2 \\
2 \\
2\end{array}$ \\
\hline
\end{tabular}

Bireysel süreçler kategorisindeki bulgular incelendiğinde “ödevler boyutu" nun önemle vurgulandığı görülmektedir. Ödevler boyutu, IYYY bireylerin ders dışı zamanlarında verilen ödev ve araştırmalarında IDÇS'nin etki potansiyeline yönelik bulguları içermektedir. Katılımcılar İDÇS'nin IYYY bireylerde ders dışı zamanlarında yaptıkları ödevlerde, anlamadıkları metinlerde ve araştırmalarında bireysel öğrenmelerine destek sağlayıcı etkisi olabileceğini belirtmiştir. Bireylerin günlük yaşamında derslerle ilgili ya da özel ilgi alanlarında karşılarına çıan kelimeleri veya metinleri anlamak için IDÇS'yi kullanabilecekleri vurgulanmıştır. Katılımcılara göre İDÇS'nin IYYY bireylerin öğrenme süreçlerinde ilgi, istek, merak uyandıracak bir sistem olduğu düşünülmektedir. Ödevler boyutuna yönelik bazı katılımcı görüşleri şu şekildedir:

"Çocuk bunu dışarıda kullandığı zaman bilmediği kelimeleri araştırabileceği için anlayabileceği için kitapta yanında başka biri olmadığı zaman olumlu etkisi olabilir. Şu açıdan baktığımızda da matematik fen Türkçe gibi anlamadığı kelimeleri anlamada ve ders dışındaki etkinliklerinde de yardımoı olacağı için akademik olarak faydası olacağını düşünüyorum."(K8). "İ̧sitme engellilerdeki materyaller daha kısıtl olduğu için bu ödev, araştırma zamanlarına da çok etkisi olacaktır." (K5). "Mesela işitme engelli anlamadığı bir şey olur bunu işaret diline çevirebilir. Metin olarak yazar oraya dediğim şekilde yapilırsa uygun bir şekilde kendi işaret diliyle anlatıldığında bu bunu demek istiyor der. Şimdi benim kardeşimde mesela anlamadığı bir şey olduğunda yazıyorlar lise mezunu kendisi zaten. Yazıyorlar anlamıyor mesela orada farklı bir kelime var mecaz anlam yok çünkü işaret dilinde mecaz anlam içeren bir cümle yazmışlar. Bana diyor ki bu ne demek diyor. Ben ona anlatıyorum durumu. Bu sistem öyle bir şey yazllacak o anlamı içeren şeyi söyleyecek o sistem kendisine. Onun ne demek istediğini anlatacak."(K3).

IDÇS'yi kullanmanın derse ayıracakları zamanları kısaltacağı yönünde de görüşlere rastlanmıştır. Bu görüşler "ders çalışması süresi boyutu" altında toplanmıştır. 4 katılımcı İDÇS'yi kullanan bireylerin daha kısa zamanda içerikleri işaret dili formuna dönüştürebilmelerinin içerik incelemeye ayıracağı zamanı azaltacağını ifade edilmektedir. Ders çalışma süresi boyutu ile ilgili katılımcı görüşlerinden bazıları şu şekildedir:

"İ̧̧aret dili bilen bir bireyin ders çalışması tabi ki de kısalacaktır çünkü çevirisini yapar otomatikman geri dönüşü daha hızl alır. Zaman kaybetmez yani karşısında program var o programa tıklayacak ya da çevirisini istediği metni girecek ya da cümleyi girecek karşıllğını direk alacak yani. Bu şekilde tabi ki de derse çalışma süresini kısaltacaktır. Bir soruyu uzun sürede anlamak vardır birde beş dakika da anlamak vardır. Otomatikman kısaltacağını 
düşünüyorum." (K9). "...en azından derse ayıracakları zamanı kısaltabilir şeklinde düşünüyorum." (K5)

Öğrenme süreçleri kategorisinde yer alan “Ders İçi Öğrenme Süreçleri” kodu IYYY bireyin sınıf içerisindeki öğrenme yaşantılarında İDÇS'yi kullanmanın öğrenme süreçlerine etkisi potansiyelini kapsamaktadır. Ders içi öğrenme süreçleri kodu "ögrretmenle iletişim süreci boyutu”, "derse katılma isteği boyutu”, "dersi anlamaya etki boyutu" ve "ders içi süreçte kullanım zorluğu boyutu" olmak üzere 4 boyutta incelenmiştir.

Ders içi öğrenme süreçlerinin ilk boyutu olan "öğretmenle iletişim süreci boyutu" IYY bireylerle öğretmen arasındaki İDÇS'nin öğrenme iletişimi sürecindeki etki potansiyelini kapsamaktadır. Katılımcılar İDÇS'nin IYY bireylerin öğretmenle kurduğu iletişim sürecine etki potansiyelinin olabileceğini belirtmiştir. Katılımcılardan işitme engelliler okulunda görev yapan öğretmenler, öğrencilerle iletişim sırasında ve unutulan kelime işaretlerinde IDÇS'yi kullanmanın hatırlamaya yarar sağlayıcı etkisi olabileceğini ifade etmişlerdir. Bununla birlikte öğretmenle iletişim süreci boyutunda ders esnasında IYY bireylerle iletişiminde sistemden yararlanarak anlatmak istedikleri kelimeleri ve ifadeleri anlatabilecekleri diğer boyutlara oranla daha sık vurgulanmıştır. Öğretmenle iletişim sürecine yönelik bazı katılımcı görüşleri şu şekildedir:

"Biz ders anlatırken mesela Fen bilgisinde dolaşım sistemi konusunu anlatıyoruz. Ben dolaşım sisteminde bazı işaretleri bilmiyorum. O an konuyu anlatırken sizin programınızı açtım diyelim çocuklara dolaşım sistemini ya da sindirim sisteminde bir organı göstereceğim. Organın işaret dili karşılığı o an aklıma gelmedi diyelim. $O$ an sizin programınızda açarım kelimeyi yazarım karşılı̆̆ı video olarak geliyor zaten. Aynı şekilde çocuklarla iletişime geçeriz çocuklarla daha rahat iletişim kurarım. Çocuklar daha rahat ders anlamıs olurlar."(K9)." Dediğim gibi derste sorusu olur öğretmene nasıl soracak? Bu sistemi kullanarak sorabilir sorusunu. Öğretmende o sistemle cevap verebilir. Bu şekilde karşılıklı iletişim daha kolay olabilir. (K3). "Biz derslerde bunu kullanabiliriz birey kendisi bir şeyler öğrenebilir ben oldukça katkı să̆layacă̆ı görüşündeyim." (K10)

Ders içi öğrenme süreçleri kodu altında yer alan ikinci boyut "derse katılma isteği boyutu" dur. 2 katılımcı tarafından İDÇS'yi kullanmanın IYY bireylerin teknolojiye olan ilgisiyle birleştirilince derse katılma isteğini arttırma potansiyelinin olduğu düşünülmektedir. Derse katılma isteğine yönelik bazı katılımcı görüşleri şu şekildedir:

"Etkiler tabi ki. Akademik başarıyı, ders çalışma isteklerini vs. etkiler. "(K10)."Derse katılma isteği konusunda çeviri yapıp kendilerine katkı sağlayabilecekleri kanısındayım." (K5)

Ders içi öğrenme süreçleri kapsamında ele alınan üçüncü boyut ise "dersi anlamaya etki boyutu" dur. Bu boyuta yönelik 2 katılımcı görüşüne göre İDÇS'nin IYYY bireylerin dersi anlamalarına yardımcı olabileceği belirtilmiştir. IYY bireylerin öğrenme sürecinde dersleri daha rahat anlamalarında İDÇS'nin etki sağlayıcı yönünde görüş ifade edilmiştir. Bununla ilgili bazı katılımcı görüşleri şu şekildedir:

"Dersi daha iyi anlamalarn derse daha iyi katılmalarna derse katılma isteklerine ders çalışma süresinin kısalması gibi süreçlere tabi çok büyük etkisi olur." (K3)

Ders içi öğrenme süreçlerinin son boyutu "ders içi süreçte kısıtlılık boyutu" dur. Ders içi süreçte kisıtlılık IYYY bireylerin ders içi öğrenmelerinde çok fayda sağlamayacağı, İDÇS'nin daha çok bireysel öğrenmeleri destekleyeceği yönündeki 
bulgularını içermektedir. Bu boyuta göre İDÇS daha çok bireysel öğrenmeleri desteklerken ders içi süreçte kısıtlı kalacağı 2 katılımcı tarafından ifade edilmiştir. Ders içi süreçte kısıtlılık boyutuna yönelik bazı katılımcı görüşleri şu şekildedir:

"Ders içi süreçlere etki etmesi biraz daha kısıth olabilir." (K10). "Bu sistemin ders adaptesini zor olarak gördüm açıkçası." (K8)

Araştırmacının katılımcı rolü olarak elde edilen bir bulgu olarak: Bireylerin IDÇS kullanarak öğrenme süreçten yararlandıklarında derslerde daha aktif hale gelecekleri görülmektedir. Türkçe, matematik ve diğer branşlarda anlamadıkları ifadelerin çevirisini yaparak öğrenme süreçlerine katkı sağlayacağı uzmanların görüşme haricindeki iletişim süreçlerinde ifade ettikleri bulgular arasındadır.

\section{Tartışma, Sonuç ve Öneriler}

IDÇS'nin IYYY bireylerin iletişim süreçlerine etkilerine yönelik elde edilen bulgular çevre ile iletişim ve işaret dili öğrenimi olmak üzere iki ayrı kategori altında değerlendirilmiştir. İDÇS'nin çevre ile iletişim sürecini etkileyen kodlara bakıldığında en çok iletişim performansını etkileme potansiyelinin olduğu belirtilmiştir. IDÇS'nin IYY bireyler ile işiten bireyler arasındaki iletişimi olumlu yönde etkileme potansiyelinin bulunduğu ve iletişimi kolaylaştıran bir rol üstleneceğine yönelik görüş bildirmiştir. Bu durum IYYY bireylerin günlük yaşantılarında büyük bir oranda IYYY veya işaret dili konuşabilen bireylerle iletişim kurmalarından dolayı iletişim çeşitliliklerinin az olması, IDÇS vasıtasıyla işiten bireyler ile iletişim kurma ihtimalinin yükselmesi düşüncesi ile açıklanabilir. Ayrıca IYYY bireylerin işiten bireyler ile olan iletişimler için yardım alma ihtiyacını ortadan kaldıracak olma ihtimali de iletişimi olumlu yönde etkileme düşüncesini ortaya çıkarmış olabilir. Yücel, Sennaroğlu ve Belgin (1996)'nin yapmış olduğu çalışmada IYY bireylerin topluma açık yerlerde (kamu kurumu vs.) iletişim kurmakta zorlandıkları ve yardım aldıkları ya da tercüman aracılığıyla iletişim kurdukları bilinmektedir. Parlak (2011) IYY bireylerin okul içerisinde işaret dilini kullanarak iletişime geçtikleri, okul dişı zamanlarda ise iletişim için dudak okuma, konuşmaya çalışma, yazma gibi yöntemleri kullandıklarını ifade etmektedir. Bununla birlikte işiten bireylerin IYY bireylerle iletişiminde kullandıkları dil işaret değil, el, kol, jest ve mimiklerle iletişim kurma davranışlarıdır. Bu durum IYY bireyleri o bireylerle iletişimde alternatif yöntemlere teşvik etmektedir. İşiten bireylerin iletişiminde de İÇS kullanımının iletişimde işiten bireye yardımcı olacağ1 düşüncesini ortaya çıkarmış olabilir. Alanyazında geliştirilen yazılımlar incelendiğinde IYY bireylerin çevre ile iletişimini arttırıcı çalışmaların olduğu görülmektedir. MTİDs 2011.v.1.1. (Mobil Türk İşaret Dili Sözlüğü) mobil uygulamasında IYY ve işiten bireylerin iletişimleri ve öğrenme düzeyleri araştırılmıştır. Çalışmada uygulamayı kullanan bireylerin diğerlerinden daha başarılı olduğu görülmüştür. Aynı zamanda IYYY bireylerle iletişime geçen yakınlarının da ihtiyacı olduğuna dair bulgulara ulaşılmıştır (Baş, 2015). Bununla birlikte alanyazında çeşitli iletişim sağlama araçları geliştirilmiştir. Bunlardan bazıları Sign 4Me, Ganas, IBM SISI, Transcense, Seslik, TID Dijital Tercümanı yazılımları olarak sıralanabilir. Yazılımlar arasında jest ve mimik eksikliği, görsellerle çeviri, 3 boyutlu avatarlarla çeviri ya da konuşmayı çevirme farklılıkları bulunmaktadır. Bu yazılımların ortak özelliği metinlerin işaret diline çevrilmesini sağlamaktır. Aynı zamanda bu tür yazılımlardan bazılarının yabancı dil destekli olması ve literatürde geliştirilen diğer yazılımların çalışma aşamasında olması da İDÇS gibi sistemlere ihtiyaç 
duyulmasından kaynaklı iletişim performansını arttırma potansiyeli olduğu düşüncesini oluşturmuş olabilir. Sonuç olarak İDÇS, IYYY bireyler ile işaret dili bilmeyen bireyler arasında iletişim köprüsü kurmak için etkin bir alternatif olarak kullanılabilir. Ayrıca araştırma sonuçlarına göre İDÇS, IYY bireyler ile işiten bireyler arasındaki iletişimi kolaylaştıran bir rol üstleneceği düşünülmektedir. İYY bireylerin çevre ile iletişiminde IDÇS'nin etkisine bakıldığında sosyalleşmeyi olumlu yönde etkileme potansiyeline sahip olduğu sonucuna ulaşılmaktadır. Doğru iletişim kurmakta zorlanan bireyler arasında problemler artar ve bu durum iletişimi azaltmalarına veya birbirlerinden uzaklaşmalarına neden olabilir. Sonuçlar IYY bireylerin İDÇS üzerinden işiten bireylerle sağlayacakları iletişimin sosyalleşmelerine katkı sağlayacağının düşünüldüğünü göstermektedir. Ayrıca IYYY bireylerin kendini ifade etme yeteneğinin gelişmesinin akademik başarı, sosyalleşme, kendini güvende hissetme, toplumda kabul gibi getirilerinin olacağı sonuçlarda ortaya çıkmaktadır. Sarıkaya ve Börekçi (2016) tarafından gerçekleştirilen IYYY öğrencilerin eğitiminde yaşanan sorunlar ve çözüm önerileri çalışmasında İYY bireylerin toplumla iletişimde problem yaşamaları halinde içe kapanıklık, toplumdan soyutlanma isteği, kendi ifade edememe, sosyal etkinliklere katılmada isteksizlik gibi davranışların ortaya çıktığı görülmüştür. Bununla birlikte IYYY bireylerin bir gruba aidiyet duygularının psikolojik ihtiyaç olduğu ve kendini ifade etmekte zorlanan İYY bireylerin sinirli davranışlar sergiledikleri de bilinmektedir (Sevinç, Aslan, ve Özkan, 2015). Baş (2015), tarafından gerçekleştirilen Mobil Türk İşaret Dili Sözlüğü çalışmasında sözlüğünün bireyler tarafından kullanımının IYY bireylerin sosyalleşmelerine katkı sağladığı, özgüven geliştirmelerinde yardımcı olduğu bulgularına ulaşılmıştır. İDÇS'nin İYY bireylerin iletişim süreçlerini arttırarak sosyalleşmelerini sağlama potansiyeli olduğu düşünülmektedir.

İşitsel sözel yöntemlerde konuşma dili İYY bireye kazandırılmaya çalışılır (MEB Özel Öğretim Kurumları Genel Müdürlüğü, 2008; MEB,2016). Bu yöntemle verilecek eğitimlerde IYYY bireyler konuşmaya kıyasla işaret dilini öğrenmeleri daha kolay olduğu için işaret diline yer verilmemesi gerekir. Bu doğrultuda IYYY bireylerin dil ve konuşma yetisinin geliştirilmesi hedeflenmektedir. Elde edilen sonuçların küçük bir bölümü, İYY bireylerin işaret dili kullanma durumlarında işitme yetisinde oluşacak tembelliğin toplumdan soyutlanmalarına sebep olabileceği yönündedir. İDÇS gibi sistemlerde IYY bireylerin işaret diline yatkınlığından dolayı kullanmaları halinde işitme duyusunda oluşacak tembelliğin konuşma dil gelişimini engellemesi, toplumdan soyutlanacakları düşüncesini ortaya çıkarmış olabilir. Ayrıca İDÇS'nin IYYY bireyler tarafından sıklıkla kullanılması sonucunda konuşma yetisinde oluşacak olumsuzluklardan kaynaklı işaret dilini kullanma tercihleri ve günlük yaşantıda işaret dilinin işiten bireylerce anlaşılamaması da İYY bireylerin iletişimini sıkıntıya sokacağı ve toplumdan soyutlayacağı düşüncesiyle açıklanabilir. Ayrıca işitme engelli okulunda eğitim gören IYY öğrencilerin \%100'e yakını iletişim kurmada işaret dilini kullandığı yapılan çalışmalarda ortaya çıkmıştır (Parlak, 2011). Bununla birlikte İYY bireylerde var olan işitme kalıntısı zamanla geliştirilebilmektedir. Bulundukları ortam var olan seslerin ayrımının yapılması sağlanabilmektedir (Girgin, 2006). Sözel iletişim becerilerini işitme kayıp derecesi, işitme cihaz kullanımı gibi durumlar etkilenmektedir. Uygun şartlar ve koşullar sağlanamadığında bireyin işitme düzeyine de bağlı olarak kullanılamayan sözel iletişim yerini işarete bırakabilir (Owens ve 
Ragrio, 1987). Bireylerin toplumsal yaşamda en etkili iletişim kurabileceği yöntem sözel iletişimdir. İşaret dili kullanımı işiten bireylerle tercüman olmadan iletişimini zorlaştıracağından zamanla toplumdan soyutlanma hissi oluşturabilir (Raimondo ve Maxwell, 1987; Hallahan ve Kauffman, 2000, Akt. Gürboğa ve Kargın, 2003). Bu nedenle geliştirilebilir işitme kalıntısına sahip bireylerin işaret dilini tercih etmesi nedeniyle işitme duyusunun tembelleşeceği düşüncesi oluşmuş olabilir. Yapılan çalışmalar incelendiğinde işaret dilinin öğrenilmesi gerektiğine dair görüşlerle birlikte işitme yetisini tembelleştirdiğinden kullanılmaması gerektiğine dair çeşitli görüşlere rastlamak mümkündür. Bu çalışmada katılımcılar IDÇS'nin IYYY bireylerin iletişim süreçlerine ve sosyalleşmelerine olumlu etki sağlayıcı potansiyelinin olduğunu sıklıkla vurgularken işaret dilini kullanmalarından kaynaklı konuşma becerilerinin zayıflamasıyla işitme kalıntısındaki oluşacak tembelliğin toplumdan soyutlanmalarına da yol açabileceğini düşünmektedir.

İDÇS sisteminin bir diğer potansiyeli ise başlangıç seviyesinde işaret dili öğrenimidir. Yapılan çalışmada sistemin iletişim süreçlerine etki sağlayacağı sonucuna ulaşılmıştır. Katılımcıların tamamı İDÇS kullanımının başlangıç düzeyinde işaret dili öğretebileceğini vurgulamıştır. Başlangıç seviyesinde işaret dili öğrenimi kelimelerin işaret dili karşılıklarıyla oluşturulmuş basit yapılı cümlelerin öğrenilmesi sonucunda IYY bireylerle sağlanacak iletişimin temelini ifade etmektedir. İşaret dili eğitimlerinin kurlardan meydana gelmesi ve başlangıç kurunda kelime anlamlarıyla işaret dilinde cümle yapılarının oluşturulması anlayışı verilmektedir. İÇS' de yer alan işaretler ve karşılıklı çevirilerin iletişimi kurmada işiten bireylere işaret dili öğrenimini sağlayacağ1 düşünülebilir. Alan yazın incelendiğin işaret dili kullanımının bireyin çeşitli alanlarda gelişimlerine etki edildiği görülmektedir. (Göl-Güven 2016).

IDÇS'nin iletişim süreçleri kapsamında işaret dili öğrenimine bir diğer etkisi ise kelime dağarcığıdır. Sonuçlar katılımcıların IDÇS'nin işiten ve IYY bireylerin iletişiminde kelime dağarcı ğını arttırıcı potansiyelinin bulunduğunu güçlü bir şekilde vurgulamaktadır. İşaret dili öğreniminde kullanılan bilişim teknolojilerinin IYYY bireylerin kelime öğrenmelerini daha hızlı sağladığı bilinmektedir (Marschark vd., 2006, Akt. Keser ve Özdemir, 2017). MacGregor ve Thomas (1988), 45 IYY bireye bilgisayar tabanlı eğitim ve e-sözlük sisteminin kullanıldı ğı bir çalışma gerçekleştirmiş ve bu sistemleri kullanan IYYY bireylerin kelime dağarcıklarında artış görülmüştür. İÇS veri tabının da yer alan kelimelerin işarete çevrilmesi, IYY bireyin tercih ettiği zaman aralıklarında kelime öğrenimine imkân vermesi, işiten bireyin merak ettikçe sistemden kelime öğrenimini gerçekleştirebileceği düşünceleri kelime dağarcı̆̆ını arttıracağı düşüncesinin oluşma nedenini açıklayabilir. Keser ve Özdemir (2017) işitme yetersizliği olan öğrencilerin eğitiminde bilgisayar destekli kelime öğretim materyali kullanımı incelediği çalışmada IYY bireylerin kelime dağarcıklarının darlığının kendilerini ifade etmelerini zorlaştırdığ1 ve bu nedenle IYYY bireylerin özgüvenini düşmesine sebep olduğu bulgusuna ulaşılmıştır. Bununla birlikte erken dönemlerde çeşitli müdahalelerle kelime dağarcıklarının anlama ve kavrama potansiyelleri, alıcı ve ifade edici dil becerileri geliştirilerek IYY bireylerin akademik başarılarına da olumlu etkisi sağlanabilir (Piştav Akmeşe, 2015). Baş (2015) tarafından geliştirilen çalışmada da geliştirilen mobil sözlük çalışmasında işaret dili videoları izlemenin kelime dağarcığını arttırdığı elde edilen bulgular arasındadır. Benzer 
şekilde bu çalışmada da IDÇS'nin işiten ve IYY bireyin kelime dağarcığını yönelik olumlu etki sağlayıcı rol üstlenebileceği görülmektedir.

IDÇS'nin işaret dili öğrenimine bir diğer etkisi ise uzmanların İDÇS'yi kullanma durumudur. İşitme engelli okullarında görev yapan lisans düzeyinden mezun öğretmenlerle yapılan görüşmelerde işaret dili öğreniminin lisans döneminde kendilerine verilmediği ve bu nedenden dolayı lisans döneminden sonra öğrencilerle karşılaştıkça bu dili öğrenmeye ve kullanmaya ihtiyaç duydukların belirtmişlerdir. Buna benzer bir bulguya Akmeşe ve Kayhan (2016)'in çalışmasında rastlamak mümkündür. Lisans programlarının karma iletişim yaklaşımlarına dayalı eğitim verilmemesinden kaynaklı sorunlar arasında katılımcılar lisans döneminde işaret dili derslerinin verilmemesi ve sonradan kendilerinin öğrenmek zorunda kaldıklarını ifade etmektedirler. Sarıkaya ve Börekçi (2016) 'nin yapmış olduğu çalışmada da işitme engeli öğretmenlerin işaret dilinde yetersiz olma gibi sıkıntılar yaşadığ1 bilinmektedir. Benzer şekilde İYY bireylere yaşıtlarılya eşit bir eğitim ortamın sağlanması açısından öğretmen yeterliliği önemli görülmektedir (Akmeşe, 2016). Bu çalışmalar öğretmenlerin işaret dili bilmelerinin İYY bireylerle geçirecekleri öğrenme yaşantılarında ve iletişim kurmalarında yeterliliklerinin önemini göstermektedir.

IDÇS'ye yönelik bulgulardan elde edilen bir diğer sonuç ise işaret dili öğrenme ilgisidir. Dünyada ve ülkemizde işaret diline olan her geçen gün daha da ilgi duyulmaktadır (Arık, 2016). Sonuçlar işaret dili öğreniminin toplum tarafından merak edilen ve ilgi duyulan bir hale geldiğini göstermektedir. Bu durumun işaret dili öğrenmelerine katkı sağlayabileceği düşüncesi nedeniyle İDÇS'nin merak duyulup kullanılabilecek bir potansiyelde olduğunu ortaya çıkarmaktadır. Baş (2015) tarafından geliştirilen mobil sözlük uygulamasında gönüllü katılımcılar işaret dili videolarını izleyerek işarete erişim kolaylığı sağladığını ve merak ettiği kelimeleri öğrenebileceği bir kaynağa sahip olduğunu ifade etmişlerdir. Akmeşe ve Kayhan'ın (2017) yaptı̆̆ çalışmada işaret dili öğreniminin sosyal medya ve reklamlar aracılığıyla popüler bir hale gelmesinden etkilendiklerini belirtmişlerdir. Benzer şekilde Akmeşe (2016) sertifika programına katılan 190 bireyle yaptı̆̆ı çalışmada işaret dili öğreniminin toplumsal yaşama etki edeceği, çeşitli kamu kurumu ve kuruluşlarda İYY bireylerin çalışma hayatına etki edeceği sonucunu ortaya koymuştur. Sonuç olarak IDÇS işaret dili öğrenmeye ilgi duyan bireyler için merak uyandıracak bir potansiyele sahip olduğu düşünülmektedir.

\section{İDÇS'nin Akademik Başarıya Etkisi}

IYYY bireylerin yaşadıkları iletişim problemleri sadece günlük yaşantılarında değil İYY bireylerin akademik yaşantılarında da kendini göstermektedir. Ayrıca bu bireyler için teknolojik materyallerin azlığ1 (Sarıkaya ve Börekçi, 2016) sorun olarak görülmüştür (Güleç-Aslan, Özbey, Sola-Özgüç ve Cihan, 2013). İYY bireylere yönelik hazırlanan materyaller konuşma ve dil gelişimi gibi alanlarda birey-kazanım arasında olumlu köprü kurabilir (Akmeşe ve Kayhan, 2016). Karal ve Çiftçi (2008) İYY bireylerin eğitim ortamında yararlanabileceği bilgisayar destekli materyallerinin anlama ve kavrama güçlüğünü ortadan kaldıracağını belirtmişlerdir (Akt. Keser ve Özdemir, 2017). Bununla birlikte TID ile ilgili görsel materyallerin arttırılması gerektiği önerilmektedir (Akmeşe, 2016). Bu bağlamda sonuçlar İDÇS'nin metin ve ses tabanlı kaynakları çevirmesinin IYYY bireylerde ders dışı zamanlarında yaptıkları ödevlerde, 
anlamadıkları metinlerde ve araştırmalarında bireysel öğrenmelerine destek sağlayıcı potansiyelinin olduğunu göstermektedir. Demirhan (2008) bilişim teknolojilerinin IYY bireylerin eğitimine etkisinin incelediği çalışmasında uygulama ve kontrol gurubu oluşturarak IYY bireylerde teknoloji kullanımının başarıya etkisini incelemiştir. Derslerde bilişim teknolojileri kullanımının IYY bireylerin ilgisini çektiği sonucuna ulaşmıştır. Benzer şekilde bu çalışmada da İYY bireylerde İDÇS'nin ilgi, istek ve merak uyandıracağı bir sistem olduğu görüşü belirtilmiştir. Ayrıca IYYY bireylerin günlük yaşamlarında derslerle ilgili ya da özel ilgi alanlarında karşılarına çıkan kelimeleri veya metinleri anlamak için IDÇS'nin fayda sağlayıcı potansiyelinin olduğu düşünülmektedir. Çalışmada İÇS'nin yazılı ve sesli kaynakları işaret diline çevirebilmesinin bireyin akademik başarısına olumlu yönde etki sağlayabilecek potansiyelinin bulunduğu sonucuna ulaşılmıştır. İDÇS'nin İYY bireylerin akademik ve ilgi alanlarındaki gelişimlerine etki sağlayabilme potansiyeli bu durumun gerekçesi olabilir. Tüm bu düşünceler ses ve metin temelli kaynakların IDÇS'nin işaret diline tercüme etmesi sonucunda IYY bireylerin ödevlerine, araştırmalarına ve bireysel ilgi alanlarında gelişimlerine katkı sağlayacağ1 düşüncesini ortaya çıkarmış olabilir. İÇS'nin işiten bireyler için hazırlanan materyalleri kullanabilmelerine de olanak tanıması bu düşünceyi ortaya çıkarmış olabilir. Çal (2011)'ın yapmış olduğu çalışmada bilişim teknolojilerinin kullanılmasının IYYY bireylerin gelişimlerine katkı sağlayacağı sonucuna ulaşılmıştır. Baş (2015) tarafından geliştirilen Mobil Türk İşaret Dili Sözlügünün de kullanımının IYYY bireylerin akademik yaşamında destek sağlayıcı bir materyal olarak görüldüğü soruları katılımcılar tarafından olumlu yanıtlar almıştır. Benzer şekilde bu çalışmada da kullanılan İDÇS'nin materyalleri işaret diline çevirmesinin bireyin materyal ve kaynak kullanım çeşitliliğini artıracağı ve IYYY bireylere akademik faaliyetlerinde katkı sağlayacağı bu nedenle akademik başarılarına olumlu yönde etki sağlayıcı potansiyelinin olduğu düşünülmektedir. Sonuç olarak İÇS'nin IYY bireylerin akademik başarılarını arttırma potansiyeline sahip bir rol üstlenebileceği düşünülmektedir. Aynı zamanda İÇS bireysel ders çalışma süreçlerine olumlu etki sağlama potansiyeline sahiptir. IDÇS'nin IYYY'lerin ders dişı bireysel öğrenme süreçlerinde ders çalışma süresini kısaltabileceği öngörülmektedir. Katılımcılar akademik çalışmalarında ve ödevlerinde İDÇS'yi kullanmalarının bilgiye hızlı erişime olanak tanıdığını bu nedenle de doğal olarak ders çalışmaya ayıracakları zamanın kısalacağını düşünmektedirler. Bu durum IDÇS ile işiten bireylere yönelik içeriklerin IYY bireyler tarafından da kullanılabileceği ve bu sayede daha kolay ve hızlı bir şekilde kaynaklara erişimin olabileceği ve bu durumun daha kısa sürede öğrenme faaliyetini gerçekleştirilebileceği düşüncesinden kaynaklanıyor olabilir.

İDÇS'nin ders içi süreçlerde en çok öğretmenle iletişim sürecine katkı sağlama potansiyelinin bulunduğu sonucuna ulaşılmıştır. Katılımcılar bu süreçte İYY bireyler ile öğrenme süreçlerinde IDÇS' den yararlanabileceklerini, unutulan ve hatırlanmaya ihtiyaç duyulan kelimelerde IDÇS'nin katkı sağlayabileceğini, öğrenci ile öğretmen iletişiminin yetersiz kaldığı durumlarda sistemin iletişimi destekleyici rol üstlenebileceğini belirtmişlerdir. Keser ve Özdemir (2017)' in yapmış olduğu çalışmada işitme engeli okuluna görevlendirilen branş öğretmenlerinin İYY öğrencilerle iletişiminde de problemlerin yaşandığı bulgusuna rastlanmıştır. Özel eğitim desteği alan veya kaynaştırma öğrencisi olan İYY bireylerin öğretmenleriyle iletişimlerinde İÇS ile ortaya çıkabilecek muhtemel iletişim probleminin giderilmesi bu bireylerin 
akademik yaşantılarında olumlu etkiler oluşturabileceği düşünülmektedir. Bununla birlikte İDÇS'nin ders içi kullanımlarının kısıtlı kalabileceğini belirtmişlerdir. İDÇS sisteminin daha çok bireysel süreçlerde bireye katkı sağlayıcı potansiyelinin olduğu ancak ders içi süreçlerde belirtilen durumların dışında kullanımının daha fazla olacağı sonucuna ulaşılmıştır. Bu durum ders içerisindeki akışın IDÇS kullanımı ile bozulabileceği veya gecikmeli iletişim oluşturabileceği düşüncesinden kaynaklanıyor olabilir. Ayrıca öğretmenlerin işaret dilini bilmiyor görünmek istememeleri anlayışı da bu duruma neden olmuş olabilir. Alanyazında öğretmenlerin işaret dili kullanımında kendilerini mezun olduktan sonrada geliştirme ihtiyacı duydukları yapılan çalışmalardan bilinmektedir (Sarıkaya ve Börekçi, 2016; Akmeşe ve Kayhan, 2016). Neticede işaret dili kullanımının derslerde ve IYY bireylerle iletişimde öğretmenler tarafından yararlı olabileceği, İDÇS'nin bazı iletişim problemlerini giderebilme potansiyelinin olduğu fakat akışı bozma veya öğretmenlerin kullanım tercihleri nedeniyle sınıf içerisinde sıklıkla kullanılma potansiyelinin bulunmadığ sonucuna ortaya çıkmaktadır.

IDÇS'nin etki edeceği bir diğer boyut olarak ders içi süreçlerde IYYY bireylerin derse katılma isteğini arttırıcı potansiyelinin olmasıdır. Katılımcılar IDÇS'nin ders süreçlerinde kullanılması, bireylerin çeviriler sayesinde kendilerini geliştirmelerine katkı sağlaması ve bunun sonucunda derse katılma isteğini arttıracağını ifade etmişlerdir. Katılımcıların IDÇS'nin ses ve metin tabanlı içerikleri çevirmesi ödevler, araştırmalar ve derse çalışması gibi sebeplere de etki edeceğinin düşünülmesi, akademik başarılarındaki ve öğrenme motivasyonlarındaki artışın sonucunda İYY bireylerin derse katılma isteğini arttıracağı düşüncesini ortaya çıkarmış olabilir. Benzer şekilde Geoffrion ve Goldenberg (1981)'in yapmış olduğu çalışmada İYY bireylerin bilgisayar destekli öğrenmede çeşitli etkinliklere katılmaya istekli oldukları gözlenmiştir. Sonuç olarak IDÇS'nin ders içinde veya dışında kullanımının IYYY bireyin derse katılma isteğini olumlu yönde etkileme potansiyeline sahip olduğu görülmektedir.

Öğrenme süreçlerine etki edeceği düşünülen bir diğer etki ise dersi daha iyi anlamaya etki etme boyutudur. IYYY bireylerin IDDÇS kullanmalarının derslerini daha iyi anlamalarına etki sağlayıcı potansiyelinin olduğu düşünülmektedir. Bu bağlamda IDÇS'nin veri tabanında bulunan kelime zenginliğinin fazla olması ve kelime hazinelerine etkilerinin düşünülmesi aynı zamanda çevresel materyallerin çevirisine imkân vermesinin IYYY bireylerin dersi anlama düzeylerini etkileyeceği düşüncesini oluşturmuş olabilir. Ayrıca akademik başarılarında meydana gelecek artışın yeni öğrenmeleri için kolaylaştırıı bir etki sağlayacağı düşüncesi de bu durumun sebebi olabilir. Çal (2011) yapmış olduğu araştırmasında IYYY bireylerin anlama ve kavrama zorluklarını azaltmaya yönelik çalışmasında, bilişim teknolojileri kullanımının IYYY bireylere olumlu etkilerinin olacağını ortaya koymuştur. Alanyazın incelendiğinde yapılan çalışmalarda IYY bireylerin anlama ve okuma düzeylerinin kelime dağarcıklarının fazlalı̆̆ı, kelimeler arasındaki anlam ilişkisini anlayabilmeleri ve eklerin algılanabilmesi gibi sonuçlardan etkilendiği görülmüştür (Kargın ve Akçamete, 1991). Sonuç olarak bu çalışmada yer alan görüşler IDÇS'nin IYYY öğrencilerin dersi anlamalarında olumlu etki sağlama potansiyeline sahip olduğu yönündedir. 
Netice itibariyle 11 katılımcıdan alınan İDÇS'nin öğrencilerin akademik başarıları ve iletişim süreçlerine etkisine yönelik uzman görüşlerinin incelenmesiyle elde edilen sonuçlar şu şekilde listelenebilir:

- İCÇS' nin İYY bireyler ile işiten bireyler arasındaki iletişimi kolaylaştırıcı, olumlu yönde etkileyici bir potansiyele sahip olabilir. Ayrıca IYYY bireylerin iletişim süreçlerini arttırarak sosyalleşmelerine imkân tanıyabilir. Ancak IYYY ve işiten bireyler arasındaki iletişimde İDÇS gibi sistemler daha çok işiten ağırlıklı kullanımları muhtemeldir.

- IDÇS'nin IYY bireyler tarafından işaret dili kullanımına göre iletişimi daha yavaş hale getirmesi tercih edilmesini engelleyebilir.

- IYY bireylerin işaret dili kullanımının konuşma yeteneğini azaltıp işitme yetisinde oluşturacağ ile sonuçlanabilir.

- IDÇS' nin işiten ve İY bireylere başlangıç düzeyde işaret dili öğrenimini kolaylaştırıcı ve sağlayıcı, kelime dağarcıklarını arttırıcı bir rol üstlenebilir.

- IYY bireylere eğitim veren öğretmenlerin işaret dili yetersizliklerinde IDÇS öğretmenlere ve işaret dili derslerinde öğrencilere katkı sağlayıcı rol üstlenebilir.

- Toplumsal ilgi ihtiyacını karşılayacak yeterlilikte olmasından dolayı IDÇS'nin ilgilenen kişiler için işaret dili öğrenimine katkı sağlayabilir.

- IDÇS, IYY kişilerin akademik başarılarını arttırıcı, ders içinde veya dışında kullanımı bireyin derse katılma isteğini olumlu yönde etkileyici, bireysel ders çalışma süreçlerine, ödevlerine, özel ilgi alanlarındaki kişisel gelişimlerine olumlu etki sağlayıcı, ders çalışmak için ayıracakları zamanı kısaltıcı, dersi anlamalarını olumlu yönde etkileyici rol üstlenebilir.

- İDÇS, kaynaştırma İYY öğrencisi veya işaret dili bilmeyen öğretmenle ders süreçlerindeki iletişimini olumlu yönde etkileyebilir.

Araştırma sonuçları katılımcı görüşlerinden oluşmaktadır. Bu görüşler uygulamalarda dikkate alınabilir ancak görüşlerin uygulamalara katkısının deneysel dayanaklı uygulamalarla incelenmesi daha detaylı sonuçlar ortaya çıkarabilir. Bu çalışma işaret dili öğretimi yapan uzmanlar ile gerçekleştirilmiştir. Benzer çalışmalar işitme yetersizliği yaşayan bireyler ile uygulamalı olarak gerçekleştirilebilir. İşaret dili çevirisi ve işaret dili öğretimine yönelik araştırmalar gerçekleştirecek araştırmacılar için şunlar önerilir;

- Hazırlanan çeviri sistemlerinin IYY bireylerin kullanım deneyimleri ile değerlendirmesi yapılabilir.

- Çeviri sistemlerinin etkilerini değerlendirmek için çevirileri anlama deneyleri gerçekleştirilebilir.

\section{Kaynakça}

Akmeşe, P.P. (2016). Examination of sign language education according to the opinions of members from a basic sign language certification program. Educational Sciences: Theory and Practice, 16(4), 1189-1225.

doi: 10.12738/estp.2016.4.0248 . 
Akmeşe, P.P. ve Kayhan, N.(2016). İşitme engelliler öğretmenleri ile odyoloji ve konuşma bozuklukları uzmanlarının işitme kayıplı çocukların eğitimi hakkındaki görüşleri. Mehmet Akif Ersoy Üniversitesi Eğitim Fakültesi Dergisi, 40, 88-122. doi: 10.21764/efd.45205 .

Akmeşe, P.P. ve Kayhan, N.(2017). İşaret dili dersine katılan öğretmen adaylarının görüşlerine göre türk işaret dili eğitiminin incelenmesi. Turkish Online Journal of Qualitative Inquiry (TOJQI), 8(1), 1-38. doi: 10.17569/ tojqi.280054.

Arık, E. (2016). Geçmişten geleceğe Türk işaret dili araştırmaları. Türk İşaret Dili Araştırmaları içinde (ss.7-22). İstanbul: Koç Üniversitesi Yayınları.

Baş, F.B. (2015). Bir mobil işaret dili uygulaması: MTIDS (Yüksek lisans tezi). Yükseköğretim Kurulu Ulusal Tez Merkezi'nden edinilmiştir. (Tez No. 464585)

Belgin E. (2003). İşitme kayıpları. Akyol U. (Ed.), Pediatrik kulak burun boğaz hastalıkları içinde (1. Baskı, ss. 31-34). Ankara: Güneş Kitabevi.

Çal, C.C., (2011). İşitme engelliler için uzaktan eğitim amaçlı, web tabanlı bir arayüz tasarımı ve uygulaması (Yüksek lisans tezi). Yükseköğretim Kurulu Ulusal Tez Merkezi'nden edinilmiştir. (Tez No.285436)

Çeliker, Z.P, ve Ege, P., (2005). İşitme engelli çocukların konuşmalarının anlaş1labilirliğini etkileyen faktörler. Ankara Üniversitesi Ĕ̆itim Bilimleri Fakültesi Özel Eğitim Dergisi, 6(1),19-32. https:// doi.org/10.1501/Ozlegt_0000000088

Çiftçi, E. (2009). İşitme engelli öğrenciler için hazırlanan bilgisayar destekli yazılı anlatım becerisi geliştirme materyalinin tasarımı, uygulanması ve değerlendirilmesi (Yüksek lisans tezi). Yükseköğretim Kurulu Ulusal Tez Merkezi'nden edinilmiştir. (Tez No. 238459).

Demirhan, T., (2008). Bilişim teknolojilerinin işitme engellilerin eğitimine etkisinin incelenmesi (Yüksek lisans tezi). Yükseköğretim Kurulu Ulusal Tez Merkezi'nden edinilmiştir. (Tez No. 179816).

Dickerson, J., Williams, S., and Browning, J. B. (2009). Scaffolding equal ssuccess in teaching tablet PCs. Thetechnology teacher, 68(5), 16-20.

Ditcharoen, N., Naruedomkul, K., and Cercone, N. (2010). SignMT: An alternative language learning tool. Computers and Education, 55(1), 118-130. https:// doi.org/10.1016/j.compedu.2009.12.009

Fang, G. , Gao, W., and Zhao, D., (2004). Large vocabulary sign language recognition based on fuzzy decision trees, IEEE Transactions on Systems, Man, and Cybernetics, Part A, 34 (3), s.305-314. https:/ / doi.org/10.1109/TSMCA.2004.824852

Fatih Projesi.10.03.2018. tarihinde http:/ / fatihprojesi.meb.gov.tr/ adresinden edinilmiştir.

Ganas. 09.07.2019 tarihinde https://www.tecnologiasaccesibles.com/en/catedras/ganas adresinden erişilmiştir.

Genç, G.A., Ertürk, B.B., ve Belgin, E., (2005). Yenidoğan işitme taraması: Başlangıçtan günümüze. Çocuk Să̆lı̆̆ı ve Hastalıkları Dergisi, 48, 109-118. 
Geoffrion, L. D., and Goldenberg, E. P. (1981). Computer-based exploratory learning systems for communication-handicapped children. The Journal of Special Education, 15(3), 325-332. https://doi.org/10.1177/002246698101500303

Girgin, M.C., (2006). İşitme Engelli Çocukların Konuşma Edinimi Eğitiminde Dinleme Becerilerinin Önemi. Ankara Üniversitesi Ĕgitim Bilimleri Fakültesi Özel Eğitim Dergisi, 7(1) 15-28. https:/ / doi.org/10.1501/Ozlegt_0000000096

Göl-Güven, M. (2016). İşitme engelli olan çocukların Türk İşaret Dili (TID) edinimini destekleyici eğitim malzemeleri geliştirme çalışması. E. Arık (Ed). Türk İşaret Dili Araştırmaları içinde (ss. 445-469). İstanbul: Koç Üniversitesi Yayınları.

Güleç-Aslan, Y., Özbey, F., Sola-Özgüç, C., ve Cihan, H., (2013). Vaka araştırması: Özel eğitim alanında çalışan öğretmenlerin sorunları ve ihtiyaçları. Uluslararası Sosyal Araştırmalar Dergisi, 7(31), 639-654.

Gürboğa, Ç., ve Kargın T. (2003). İşitme engelli yetişkinlerin farklı ortamlarda kullandıkları iletişim yöntemlerinin/becerilerinin incelenmesi. Journal of Faculty of Educational Sciences, 36, 51-64. https://doi.org/10.1501/Egifak_0000000074

IBM SISI (2007). 10.10.2018 tarihinde http:/ / mqtt.org/ projects/sisi adresinden erişilmiştir.

Karacan, E. (2000). Bebeklerde ve Çocuklarda Dil Gelişimi. Klinik Psikiyatri. 3, 263- 268 27.01.2020 tarihinde https://www.journalagent.com/kpd/pdfs/KPD_3_4_263_268.pdf adresinden erişilmiştir.

Kargın, T., ve Akçamete, G., (1991). Bireyselleştirilmiş eğitim programı, işitme engelliler ve okuma. Ankara Üniversitesi Ĕ̆itim Bilimleri Fakültesi Dergisi, 24(1), 151-160.

Keser, H., ve Özdemir, O. (2017). İşitme yetersizliği olan öğrencilerin eğitimlerinde bilgisayar destekli kelime öğretim materyali kullanımının incelenmesi. Ankara Üniversitesi Eğitim Bilimleri Fakültesi Özel Eğitim Dergisi, 19 (1), 29-53. https:// doi.org/10.21565/ozelegitimdergisi.300290

Kizir, M., ve Çifci-Tekinarslan, İ. (2016). İşitme yetersizliği olan bireylere sosyal beceri öğretimi: Bir gözden geçirme. Current Research in Education, 2(3), 149164.

MacGregor , S.K. and Thomas, L.B. (1988). A computer-mediated text system to develop communication skills for hearing 1mpaired students. American Annals of the deaf, 133(4), 280-284. https:/ / doi.org/10.1353/ aad.2012.0709

Marschark, M. (2007). Raising and educating a deaf child: A comprehensive guide to the choices, controversies, and decisions faced by parents and educators (2nd Edition). New York: Oxford University

Mayberry, R.I. and Squires, B.( 2006). Sign language:Acquisition. History of research. In. K. Brown (Ed.) Encyclopedia of language and linguistics: Sign Languages (pp.291-296). Oxford:Elsevier https:/ / doi.org/10.1016/B0-08-044854-2/008543

MEB Özel Öğretim Kurumları Genel Müdürlüğü (2008). Özel Eğitim ve Rehabilitasyon Merkezi İşitme Engelli Bireyler Destek Eğitim Programı. Ankara.

MEB (2016). Çocuk Gelişimi ve Eğitimi. İşitme Yetersizliği.Ankara 
Merriam, S.B. (2013). Nitel Araştırma Desen ve Uygulama İçin Bir Rehber, (Çev.Editörü: Selahattin Turan). Ankara: Nobel Yayınları.

Milli Eğitim Bakanlığı. (2018-2019). Millî Eğitim İstatistikleri Örgün Eğitim. 26.01.2020 tarihinde http:/ / www.meb.gov.tr/ adresinden erişilmiştir.

Murzaeva, A., Panik, H., Abay, Z., ve Yorulmaz, E. (2017). Yazı ve sesi işaret diline çeviren mobil bir uygulama (Seslik). Akademik Bilişim Konferansı, Aksaray. 15.08.2018 tarihinde https://ab.org.tr/ab17/bildiri/51.pdf adresinden edinilmiştir.

Owens, E., and Ragrigo, M. (1987). The UCSF tracking procedure for evaluation and training of speech reception by hearing-impaired adults. Journal of Speech And Hearing Disorders, 52, 120-128. https:// doi.org/10.1044/jshd.5202.120

Parlak, S. (2011). Türkiye'deki işitme engelliği ve işletmelerdeki danışmanlık hizmetleri üzerine bir pilot çalışma. Bursa: Ekin Basın Yayın Dağıtım.

Paul, P. V. (2001). Language and deafness. San Diego, CA: Singular

Piştav Akmeşe, (2015). Doğuştan ileri/ çok ileri derecede işitme kayıplı çocukların dil becerilerine ilişkin araştırmaların incelenmesi. Ege Eğitim Dergisi, 16(2), 392407. https:/ / doi.org/10.12984/eed.60663

Sarıkaya, B., ve Börekçi, M. (2016). İşitme engelli öğrencilerin eğitiminde yaşanan sorunlar ve çözüm önerileri: Erzurum ili örneği. Ekev Akademi Dergisi, 66, 177 193. https:/ / doi.org/10.17753/Ekev646

Selvi, H., (2004). Resmî işitme engelliler eğitim kurumlarmın işlevsel süreçlerinin değerlendirilmesi (Yayımlanmamış yüksek lisans tezi). Marmara Üniversitesi, İstanbul, Türkiye.

Sevinç, Ş., Aslan, F., ve Özkan, B. (2015). İşitme engelliler için öğretmen kılavuz kitabı. Özel Eğitim ve Rehberlik Genel Müdürlüğü.

SignAloud, (2017). 11.09.2019 tarihinde https:// www.interactiveaccessibility.com/news/signaloudgloves\#.XX_LyegzbIU adresinden edinilmiştir

Sign 4 Me. 10.03.2018 tarihinde http:/ / www.signingapp.com/index_desktop.html adresinden erişilmiştir.

Spread The Sign. 26.07.2019 tarihinde https:/ / www.spreadthesign.com/tr.tr/about/ adresinden erişilmiştir.

Şahlı, S., ve Belgin, E. (2011). Ülkemizde işitme kayıplı çocukların profili ve tedavi yaklaşımları. Hacettepe Tıp Dergisi, 42, 82-87.

TİD Dijtal Tercüman. 09.08.2018 tarihinde http:/ / www.panteon.com.tr/tid/ adresinden edinilmiştir.

Transcense. 12.09.2018 tarihinde https:/ / www.ava.me/ adresinden edinilmiştir.

Trezek, B. J., and Wang, Y. (2006). Implications of utilizing a phonics-based reading curriculum with children who are deaf or hard of hearing. Journal of Deaf Studies and Deaf Education, 11(2), 202-213. https:// doi.org/10.1093/deafed/enj031

TÜİK (2010), Türkiye İstatistik Kurumu - Özürlülerin sorun ve beklentileri araştırması. 10.03.2018 tarihinde www.turkstat.gov.tr/IcerikGetir.do?istab_id=5 adresinden edinilmiştir. 
Yasan, M.C., (2014). Türkçe metni Türk işaret diline dönüştürme (Yüksek lisans tezi). Yükseköğretim Kurulu Ulusal Tez Merkezi'nden edinilmiştir. (Tez No. 364246).

Yücel, E., Sennaroğlu, G., ve Belgin, E. (1996, Aralık). İşitme engelli yetişkinlerin sosyal ortamlardaki iletişim problemlerinin araştırılması. Poster özürlü kent ve çevre kongresinde sunulmuştur. Ankara: Hacettepe Üniversitesi.

Yıldırım, A. (1999). Nitel araştırma yöntemlerinin temel özellikleri ve eğitim araştırmalarındaki yeri ve önemi. Ĕ̈itim ve Bilim, 23(112).

Yıldırım, A., ve Şimşek, H. (2008). Sosyal bilimlerde nitel araştırma yöntemleri (6. Baskı). Ankara: Seçkin Yayıncılık.

\section{Summary}

\section{Introduction}

Hearing is an important sense which enables one to communicate with environment, to develop some areas such as intellectual, linguistic and cognitive etc. (Genç, Ertürk and Belgin 2005). Hearing's taking a disincentive role on learning, communication and other skill areas is called hearing loss (Belgin, 2003). By means of sense of hearing, ability to speak can develop, surrounding events could be perceived better and vocabulary can be extended. People who can hear show awareness to surrounding sounds, recognise the voices and learn their languages by making progresses in expected time periods (Karacan, 2000). A person who can hear is able to differentiate the surrounding sounds, realize the rhythm and intonation, give meaning to sounds $\mathrm{s} /$ he hears and by means of it, s/he can expand their vocabulary knowledge (Cole, 1992; Akt. Çeliker and Ege, 2005). However, since a person who is IYY lacks of these experiences, her/his inability affects their social skills in a negative way (Kizir and Tekinaslan, 2016). In addition to this, IYYs' language problems affect their communication skills and academic life (Marschark, 2007). Besides IYY people have to make progress with less variety of learning environment than hearing people. Their inability of making use of auditory materials, not being able to use written and printed sources because of their having difficulties on literacy (Selvi, 2004), IYY people's education's taking longer compared to hearing people (Paul, 2001) and lack of materials specially prepared for such people in educational environment (Sarikaya and Börekçi, 2016) make their personal development difficult.

When literature is reviewed, lack of studies for IYY draws attention. Besides, it seems that the materials and sources prepared fall short and are not enough for meeting the needs of such people (Demirhan 2008; Keser and Özdemir, 2017; Sarıkaya and Börekçi, 2016). Physical conditions and lack of family attention (Sarkkaya and Börekçi, 2016), lack of mental lexicon (Sarıkaya and Börekçi, 2016; Keser and Özdemir, 2017; Çiftçi, 2009), lack of device (Sarıkaya and Börekçi, 2016) are amongst the other encountered problems. As for teachers, it is known that they have problems in the areas on leaving sign language to be desired, parent-teacher collaboration (Sarıkaya and Börekçi, 2016).

Creating an environment which provides the communication IYY people need in their daily life and pays attention to our cultural aspects would help for solving communication problems. The study has the potential of making an important 
contribution on utility of solutions developed on such perspective, attainability of proper outcome and in terms of being supportive on development of both daily and academic life. Forming opinions that focus on experiences such us shedding light on developed solutions, increasing activity, being able to design for differences, and that are aimed at system designs of experts would contribute to overcoming the communication problems IYY people had.

The aim of this study is to determine the potential of the IDCS developed as a communication environment to support the communication process and academic success. Within this scope, answers of these questions will be researched:

1. What are the expert opinions on developed IDCS?

a. What are the expert opinions about impact potential of developed IDCS on people's communication process?

b. What are the expert opinions about impact potential of developed IDCS on IYY students' academic success?

\section{Method}

The study was conducted with case study which is one of the qualitative research methods. The study group of the study consists of 11 experts including special education teachers who graduated from hearing impaired teachers, specialist teachers and sign language interpreters. The system was designed considering the deficiencies in the literature and the development process was carried out. After the necessary arrangements, expert opinions about the system were obtained and the collected data were analyzed. The data were collected under two themes: communication processes and academic achievement. When the findings related to the communication processes are analyzed, it is thought that the IDCS has the potential to increase communication performance and socialization mostly. However, it has been said that IDCS has the potential to learn sign language at starter level and increase vocabulary by perticipents.)

\section{Discussion and Results}

It is indicated that, when the codes that affect the communication process with environment are examined, IDCS have the potential to affect the communication performance the most. This can be explained with lack of communication variety caused by IYY people's mostly communicating with IYY people or sign language speakers in their daily life, the thought of increasing the possibility of communication with hearing people via IDCS. It is known in the study of Yücel, Sennaroğlu and Belgin (1996) that IYY people have difficulties on communication and have help or communicate via translator in the public domains (public institute etc.).

It comes to the conclusion that, when effects of IDCS on the communication of IYY people with environment are examined, IDCS have the potential of affecting the socialising in a positive way. It is seemed in the study of the problems that IYY students have and suggestions of solutions by Sarıkaya and Börekçi, in the event of IYY people having communication difficulties with society, behaviours such as introversion, desire of isolation from society, lack of self-expression skill, unwillingness of participating social events emerge. In addition to this, it is known that the IYY people's sense of belonging to a group is a psychological need and IYY 
people who have difficulties on self-expression display nervous behaviours (Sevinç, Aslan, and Özkan, 2015).

Another potential of IDCS system is learning beginner level sign language. It is concluded in the study that the system will have effect on communication processes. All of the participants emphasized that use of IDCS could teach beginner level of sign language. When body of literature is examined it seems that use of sign language affects the development of an individual on various fields Göl-Güven 2016).

It has been found that IDCS has the potential to increase communication performance, socialization, vocabulary, academic achievement, sign language learning and interest in sign language learning. It is also among the results that laziness in hearing ability can lead to abstraction. With the results that the results acquired by examining expert opinions towards the impacts of IDCS on students' academic success and communication process taken from 11 participants can be listed as below:

- IDCS may have a facilitator of communication between IYY people and hearing people and positively effectual potential. Besides, it may enable IYY people to socialise by increasing their communication process. However, in the communication between IYY people and hearing people, it is possible that systems such as IDCS to be used mostly by hearing people.

- IDCS's slowing down the communication compared to the utility of sign language by IYY people may hamper its preferabilty.

- The probability of laziness on hearing ability less use of talking skill caused by IYY people using sign language may end up their being abstracted from society.

- IDCS may have a learning beginner level sign language among hearing and IYY people facilitator and provider, and vocabulary additive role.

- IDCS may take a contributor role on sign language inefficacy of teachers who give education to IYY people and on students in sign language lessons.

- Since it is up to fulfil the social attention need, IDCS may contribute to sign language learning by people who are interested in.

- IDCS may take an increaser role of academic success of IYY people; its being used during lesson may take positively effector role of participating, individual studying process, homework, personal development on specialities; it may take a shortener role of time that they spare for studying, positively effector of understanding the lesson.

- IDCS may positively affect the communication of IYY inclusive student or teacher who does not speak sign language during lesson.

\section{Pedagogical Implications}

The results of the research consist of participant opinions. These opinions can be taken into consideration in the applications, but examining the contribution of the opinions to the applications with experimentally based applications may reveal more detailed results. Similar studies can be implemented with individuals with hearing impairment. For researchers who will carry out research on sign language translation and sign language teaching, the following is recommended;

- The prepared translation systems can be evaluated with the experience of using IYY individuals. 
- Understanding translations can be carried out to evaluate the effects of translation systems.

\section{Authors' Biodata / Yazar Bilgileri}

Takdire VİŞNE Atatürk Üniversitesi Bilgisayar ve Öğretim Teknolojileri Eğitimi Anabilim Dalı Bilgisayar ve Öğretim Teknolojileri Eğitimi Alanında Yüksek Lisansını 2019 yılında tamamlamıştır. Milli Eğitim Bakanlığında 4 yıldır Bilişim Teknolojileri ve Yazılım Öğretmeni olarak görev yapmaktadır.

Takdire Visne completed her master's degree at Atatürk University Computer Education and Instructional Technologies Department in 2019. She has been working as a Information Technologies teacher at the Ministry of Education for 4 years.

Serkan YILDIRIM Atatürk Üniversitesi Bilgisayar ve Öğretim Teknolojileri Eğitimi Anabilim Dalı, Bilgisayar ve Öğretim Teknolojileri Alanında Doktor Öğretim Üyesi olarak görev yapmaktadir.

Serkan Yildirim works as a lecturer at Atatürk University, Faculty of Education, Department of Computer Education and Instructional Technologies, Computer Education and Instructional Technologies Department. 